\title{
Article \\ The Challenges of Political Corruption in Australia, the Proposed Commonwealth Integrity Commission Bill (2020) and the Application of the APUNCAC
}

\author{
Marie J. dela Rama ${ }^{1, *(\mathbb{D},}$, Michael E. Lester ${ }^{2}(\mathbb{D})$ and Warren Staples ${ }^{3}(\mathbb{D}$ \\ 1 Business School, University of Technology Sydney, Sydney, NSW 2007, Australia \\ 2 Independent Researcher, Sydney, NSW 2000, Australia; melester@yahoo.com \\ 3 Melbourne School of Government, University of Melbourne, Carlton, Melbourne, VIC 3053, Australia; \\ warren.staples@unimelb.edu.au \\ * Correspondence: marie.delarama@uts.edu.au
}

Citation: dela Rama, Marie J., Michael E. Lester, and Warren Staples. 2022. The Challenges of Political Corruption in Australia, the Proposed Commonwealth Integrity Commission Bill (2020) and the Application of the APUNCAC. Laws 11: 7. https://doi.org/10.3390/ laws11010007

Received: 5 December 2021

Accepted: 7 January 2022

Published: 13 January 2022

Publisher's Note: MDPI stays neutral with regard to jurisdictional claims in published maps and institutional affiliations.

Copyright: (c) 2022 by the authors. Licensee MDPI, Basel, Switzerland. This article is an open access article distributed under the terms and conditions of the Creative Commons Attribution (CC BY) license (https:// creativecommons.org/licenses/by/ $4.0 /)$.

\begin{abstract}
Political corruption affects each nation-state differently, but the outcomes are nominally the same: a deficit of public trust, weakened government institutions and undermined political systems. This article analyzes issues of political corruption in Australia by framing them within a national integrity ecosystem (NIE) and addressing them against the proposed Commonwealth Integrity Commission (CIC) 2020 bill. It also discusses prevalent 'grey' areas of Australian politically-corrupt behavior where they interact with the private sector: the revolving door, political donations, and lobbying; and the state of Australia's implementation of the OECD Anti-Bribery Convention. This article argues for their inclusion within the mandated scope of the proposed CIC. There is a need for strong legislation, both domestic and international, to fight corruption. This article then discusses the application of the provisions of the draft Anticorruption Protocol to the UN Convention Against Corruption (APUNCAC) that may apply with respect to these 'grey' issues, and how an International Anti-Corruption Court may provide another institutional model for Australia to follow. Finally, this article links these proposals to the 2021 UN General Assembly Special Session (UNGASS) on Corruption and the 9th Conference of States Parties on the UNCAC (COSP9). These events illustrate multilateral momentum and progress on anti-corruption. As a country that has historically supported the UN multilateral framework and its institutions, this article recommends a proactive approach for Australia so that the passing of a strong domestic anticorruption initiative will contribute to the adoption, and eventual ratification, of the APUNCAC.
\end{abstract}

Keywords: APUNCAC; Australia; bribery; CIC; conflicts of interest; convention; corrupt behavior; corruption; COSP9; COVID-19; IACC; ICAC; integrity; integrity system; lobbying; multilateral cooperation; OECD; political corruption; political culture; political donations; procurement; public officials; revolving door; Transparency International; UN; UNCAC; UNGASS; UNODC

\section{Introduction}

Corruption involves the misuse of public position for private gain (Rose-Ackerman 2008; Shleifer and Vishny 1993). Integrity is the appropriate use of public power for public ends (Huberts 2014). The latter sets the standard and associated processes, while the former is a deviation from that standard and practice. Both integrity and corruption are present along a spectrum of behaviors within democratic institutions (Uslaner 2013). These institutions reflect both the historical and current political will in terms of their values, representation, and operational responsibilities. Such institutions should serve the interests of all, not just the politically connected nor powerful few.

Any purchase of preferential access to public officials by the private sector-whether through the promise and/or inducement of employment after their public service, lobbying 
them whilst in office or donating to the party that they represent-undermines public confidence in democratic institutions (Prenzler et al. 2018; Warren 2004). Overseas jurisdictions have demonstrated that weakened democratic institutions affect the long-term health and stability of societies and are not in the broad, utilitarian interest of a nation (Lawder 2021; Leng 2020; Packer 2020; Siddiquee and Zafarullah 2020).

This article seeks to answer the following questions: What issues are raised by Australia's proposed Commonwealth Integrity Commission (CIC) bill and strategy to deal with political corruption? Furthermore, how does the bill compare to international anticorruption instruments?

\section{The Problems of Political Corruption in Australia}

Political corruption in Australia has reached a point where prominent figures freely express their disdain regarding measures to promote transparency. For example, Daryl Maguire, former New South Wales (NSW) Member of Parliament (MP) for Wagga Wagga, stated:

We have become fucking harlots and prostitutes through no fault of our own because of these, you know, rules of transparency, of you know of arm's length of not talking to this person or that person, or bloody ICAC or everything else. (NSW ICAC 2021, p. 2)

This type of response suggests a need for corrective action, to impose changes that alter the ecosystem surrounding public officials so that they accept the need for transparency and public accountability.

Political corruption is corruption committed by actors and stakeholders in the political arena with deleterious effects (Ceva and Ferretti 2017; Harris 2003; Rose-Ackerman 1999). Macallister (2014) noted the increasing disquiet about public concerns of corruption in Australia. Instances of political corruption with little transparency or accountability have occurred under ministerial discretion and direction and have been documented by Prenzler et al. (2018) regarding the Abbott Government; Grafton and Williams (2020) over the Murray-Darling Basin case; Hasler (2020) over the Carmichael mine case; and Dixon (2020) regarding Commonwealth cases involving public grant spending in support of vested or partisan interests (such as but not limited to 'sports rorts' ${ }^{1}$, the Great Barrier Reef Foundation, 'car park rorts,' 2 and 'Watergate'). The normalization of these 'pork barrel', 'spoils of office' practices where marginal seats, or seats held by the ruling political party receive more public funding, was publicly acknowledged in the remarks of the former NSW Premier Gladys Berejiklian:

It's not something [pork barreling] the community likes ... but it's an accusation I will wear ... It's not unique to our government ... It's not an illegal practice. Unfortunately, it does happen from time to time by every government. (in Davies 2020)

There is similarity between this pattern of conduct and Rose-Ackerman's (2008) description of the early stages of grand corruption. This contemporary political behavior and culture has had an impact on Australia's international anti-corruption standing and transparency ranking. In 2021, Australia was removed from the top 10 countries in Transparency International's Corruption Perceptions Index for the first time (Transparency International 2021a). This is a notable decline of eight places since 2012 (Transparency International 2021b), when it was ranked 7th, equal with Norway; and four places behind its neighbor New Zealand which was equal first with Finland and Denmark (Transparency International 2012).

1 Australian Select Senate Committee on the Administration of Sports Grants (2021). Final Report. https://www.aph.gov.au/Parliamentary_Business/Committees/Senate/Administration_of_Sports_ Grants/AdminSportsGrants/Report (accessed on 4 December 2021).

2 Australian National Audit Office (2021). Administration of Commuter Car Park Projects within the Urban Congestion Fund, 28 June. https://www.anao.gov.au/work/performance-audit/administration-commuter-car-parkprojects-within-the-urban-congestion-fund (accessed on 4 December 2021). 
The country's gradual decline in Transparency International's Corruption Perceptions Index from 2013 to 2017 coincided with a period of instability in the political leadership of the country when it experienced four different Prime Ministers in four years: Julia Gillard (2010-June 2013), Kevin Rudd (June 2013-September 2013); Tony Abbott (September 2013 September 2015) and Malcolm Turnbull (September 2015-September 2018).

In 2021, while New Zealand still ranked first on this index, tied with Denmark; Australia's peer comparator Norway remained at 7th place but the country was now at 11th place joining Canada, the United Kingdom and Hong Kong (Transparency International 2021a). This decline is notable as Australia had largely followed the Scandinavian models in social policy (Deeming 2014; Schwartz 1998; Scott 2009), and it was held up as a country where anti-corruption lessons and corruption prevention strategies can be learnt from (Larmour 2001; Williams 1999).

Similar to other experiences overseas (Barrett and Reuben 2021; Lester et al. 2021), the COVID-19 pandemic response has involved billions of public monies being allocated preferentially to ruling political party donors such as Aspen Medical (Anderson 2016; Harrison 2015; Mizen 2020) which hired former federal Health Minister Michael Wooldridge as a lobbyist (Lucas and Schneiders 2020). The secretive nature of pandemic response spending has fueled the perception that there is a lack of accountability in government. The 2020-2021 budget (delayed to October 2020 instead of its usual May release due to the pandemic) has been described as 'the least transparent on record' (Feik 2021). Sovereign corruption risk can translate into significant sovereign credit risk (Connolly 2007). The next section provides a framework which contextualizes corruption, and its polar opposite integrity, in Australia.

\section{A National Integrity Ecosystem (NIE)}

Democracy is government by the people for the people; plutocracy is government by the elites for the wealthy; kleptocracy is government for the enrichment of public officials. Political corruption undermines public trust in democratic institutions (Pellegatta and Memoli 2016; Uslaner 2002, 2013, 2017). The moral problem of corruption arises when the political process for elected officials in governments, expressed in legislation, is perverted by undue private influence of vested interests over public policy and decision making. Political corruption is also a matter of culture which covers behaviors ranging from the outright illegal to grey areas (Prenzler et al. 2018; Soreide 2007, p. 340).

Figure 1 depicts factors influencing the behavior of public officials. The policies of deregulation, neoliberalism, privatization and the role of the country's elite networks influence the level of corruption. Institutions, state Independent Commission Against Corruptions (ICACs), the CIC bill, the UN Convention Against Corruption (UNCAC), the Anti-Corruption Protocol of UNCAC (APUNCAC), and community culture and values influence the degree to which corruption impacts the behavior of public officials. These elements influence the degree of accountability, transparency, and integrity, which in turn influences the level of public trust in public officials and the government. In other words, the installation of strong institutions, state ICACs, a strong CIC bill, the UNCAC, and the APUNCAC embodies and bolsters community culture and values that reject corrupt practices; and reduces the influence of corruption, promotes accountability, integrity, and transparency; this in turn promotes public trust in government. Public officials-both elected (politicians) and appointed (civil servants; public servants or bureaucrats) —are the salient stakeholders in this ecosystem (Mitchell et al. 1997). The behavior of public officials is shaped by a sea of influences which ultimately shape public perceptions of the level of accountability, transparency, integrity and trust in the political system and the nation's governing institutions. 


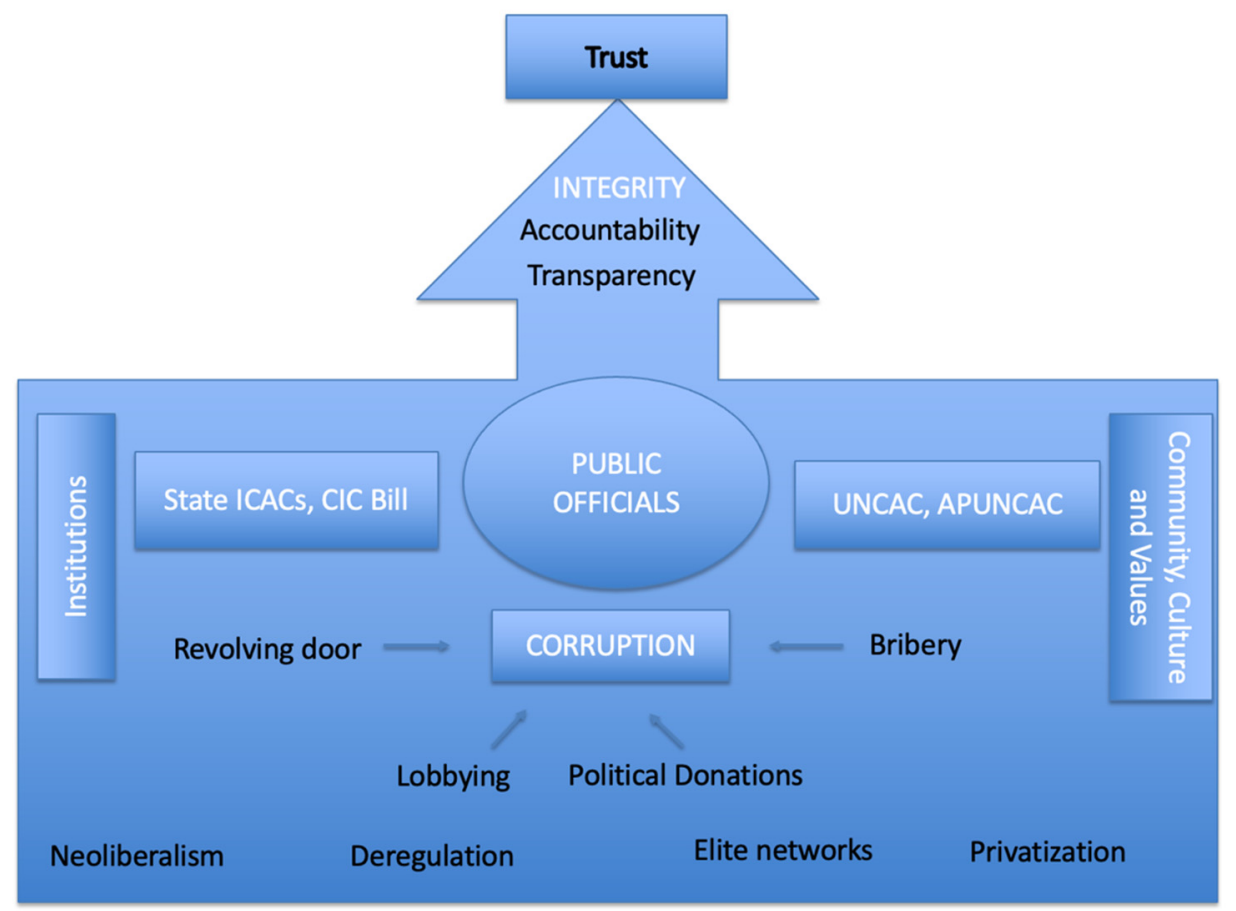

Figure 1. Model of Australia's integrity ecosystem.

In this model, trust is conceptualized as the ideal outcome. Accountability and transparency are levers to achieve integrity. Corruption is viewed as the deleterious outcome of multiple interacting factors. Culture and values, institutions, domestic and international instruments, events, and policy trends impact the public's perception of the level of government corruption. Domestic and international instruments include the proposed CIC bill, the UNCAC (which was ratified by Australia in 2005) ${ }^{3}$, and the potential impact of the APUNCAC.

Treviño and Nelson (2021) argue that leaders, through the 'tone at the top,' have an enormous impact on ethical culture within organizations. When a country's political leaders engage in corruption, they implicitly sanction a culture of corruption which then becomes embedded and normalized in its institutions (Vallance 1999; World Bank and Asian Development Bank 2003). When political corruption becomes systemic and institutionalized and immoral political behavior favoring powerful individuals over public interest is rampant, it becomes 'rationalized' and 'normalized.' New entrants are then acclimatized to this culture, inducted, and socialized as this way of normalized behavior is reproduced. If like attracts like, those who do not engage in corrupt conduct will be deterred and will avoid employment at public institutions that have normalized such corrupt behavior (Ashforth and Anand 2003). To counteract the perception of the normalization and institutionalization of corruption, there have been efforts to institutionalize integrity as a norm and embed it into expectations regarding the behavior of public officials (Costigan 2005; Sampford et al. 2005; Williams 1999).

Neoliberal policies of deregulation and privatization have been part of the Australian political landscape since the 1980s (Quiggin 1999). They influence the integrity system through the involvement and influence of Australia's business elite networks (Bell and Hindmoor 2014; Marsh et al. 2014; Murray 2006). Formal channels include institutions, fora, and agreements. Informal channels include elite/oligarchical networks, civil society activism, and public interest media. Figure 1 highlights four pertinent issues in the Aus-

3 UN Office of Drugs and Crime-Signature and Ratification Status. https://www.unodc.org/unodc/en/ corruption/ratification-status.html (accessed on 4 December 2021). 
tralian political corruption context: bribery, and the three forms of grey corruption namely the revolving door, political donations and lobbying.

There is a need to create a robust national integrity ecosystem that supports a political culture that is allergic to corruption and embraces sunlight when public monies, policy decisions and public duties are involved. One possible and long mooted contributor to this integrity ecosystem is a federal anti-corruption commission. The proposed CIC bill is a measure that seeks to institutionalize this type of anti-corruption commission.

\section{A Federal Integrity Commission}

The first Australian state anti-corruption commission in NSW was established by then Premier Nick Greiner in 1988 following the Hong Kong ICAC model. The NSW ICAC is an anti-corruption body that is publicly empowered and committed to pursue and protect the public interest above private self-interest or partisan, political party interest. Greiner himself became one of its most notable scalps (Tanner 1995; Williams 1999).

As various state ICACs have been established across Australia, civil society has called for a federal version of an anti-corruption commission to deal with political corruption on the federal level (Aulby 2017; The Australia Institute 2019; Griffith University and Transparency International Australia 2017; Hobbs and Williams 2017).

A generation after NSW ICAC's establishment, the details of the CIC draft bill to establish a federal anti-corruption agency were published in November 2020 by the Morrison Government. ${ }^{4}$ This section discusses the major issues we find in the CIC bill.

\subsection{Problems with the Proposed CIC Bill}

Nominally, an integrity commission supports and enhances the integrity of public institutions and their holders; and holds the privileged and responsible to account when it comes to public monies and their disbursement (Meagher 2005). With the publication of the draft bill, it has been argued by leading jurists that the contents of the bill do the opposite and deviate from the norms established by the largely successful state ICACs (Charles 2020; Cowdery 2020). Tensions have arisen over the current form of the CIC bill where efforts to protect the reputation of public office holders (based on natural justice, due process, and burden of proof principles) may compromise the efforts of the proposed anti-corruption agency to prevent, investigate and expose corruption. The following subsections examine in detail sections of the bill that require further enhancement: namely, sections regarding definitions, risk management, bifurcation of standards applied to public officials, and the failure to incorporate public hearings.

\subsubsection{Definition of Corruption and Integrity}

In Australia, grey corruption (such as lobbying, political donations, revolving door movements, and a lack of transparency in the tenders and contracts process) involves private or vested interests seeking preferential treatment, or acting preferentially, against the public interest but is not illegal or criminal per se. Whilst not illegal, these acts have the effect of undermining democratic trust and reduce certainty in the administration of due process in public institutions. However, CIC bill does not cover broader 'grey' area manifestations that are neither illegal nor criminal in nature but reflect amoral behavior vis-à-vis the public interest (Jackson et al. 2008). There is a need to define 'integrity' broadly to exclude acts of 'political' corruption (Kirby 2020). The terms 'political corruption', 'corruption' and 'integrity' are narrowly defined and could be expanded in Part 2, Division 1, Section 5 of the CIC bill. Expanded definitions would help to address grey areas of political corruption prevalent in Australia.

4 Attorney-General's Department (2020). CIC Consultation Draft Bill 2020. https:/ /www.ag.gov.au/integrity/ consultations/commonwealth-integrity-commission-consultation-draft (accessed on 4 December 2021). 


\subsubsection{Sovereign and Institutional Risk vs. Personal Reputational Risk}

Sections 99, 10, 182, 184, 239 and 243 of the bill seek to protect the reputation of a person who is the subject of an investigation. Section 243 states that before the public release of reports, the Minister in charge must "remove information ... that may unfairly prejudice a person's reputation." This is problematic because this language favors the protection of private interests, serving to shield those interests from the reputational damage of a corruption investigation, over the protection of the public interest in knowing the identities of public officials who may be involved in corrupt acts.

Mulgan (2007) highlights the increasing politicization of both advice and appointment processes in the Australian Public Service. The language in the bill protecting a person's reputation appears to have been inserted under the purview of Margaret Cunneen, a member of the CIC advisory committee. Cunneen is a high-profile Crown prosecutor who herself had allegedly engaged in the type of conduct that the CIC advisory committee was charged to advise upon (Chenoweth 2016; Doran 2018). Her appointment to the CIC advisory committee may have been motivated on the basis of partisan sympathy and signals an alignment between politicians and those in charge of developing a federal ICAC and their preferences regarding the structure and scope of the proposed CIC bill.

A person's reputational risk, as considered in the bill, is not the risk to ordinary citizens but 'public officers' who are entrusted with a 'public interest' duty and remunerated at the taxpayers' expense. By accepting a public position of trust and privilege, these individuals assume responsibility and public accountability in the exercise of their public duties (Ceva and Ferretti 2017). Improprieties involve the use of their positions to obtain or solicit an advantage - financial, personal, or otherwise - that an ordinary person is not able to access due to their political power and/or class. There is asymmetrical information in such an environment. Any exercise of such actions based upon privileged information requires greater public scrutiny as this may constitute a fundamental conflict between public duty and private gain. For example, the MP for Wentworth Dave Sharma's investment portfolio includes share ownership of firms in receipt of government contracts (Wilkins 2020). There is a growing body of research on addressing and managing the risks posed by politically-exposed persons (PEPs) such as public officials, their relatives and close associates (Choo 2008; Greenberg et al. 2010; Menz 2021; Shill 2020).

Article 2 (a) of the UNCAC, to which Australia is signatory, defines public officials comprehensively:

"Public official" shall mean:

any person holding a legislative, executive, administrative or judicial office of a State Party, whether appointed or elected, whether permanent or temporary, whether paid or unpaid, irrespective of that person's seniority;

any other person who performs a public function, including for a public agency or public enterprise, or provides a public service, as defined in the domestic law of the State Party and as applied in the pertinent area of law of that State Party; any other person defined as a "public official" in the domestic law of a State Party. However, for the purpose of some specific measures contained in chapter II of this Convention, "public official" may mean any person who performs a public function or provides a public service as defined in the domestic law of the State Party and as applied in the pertinent area of law of that State Party; ${ }^{5}$

The bill should ensure that it meets its UNCAC obligations both in the intent and spirit of the Convention and should, accordingly, adopt the above definition of a public official. Currently, the bill positions the reputational risk of a person above the sovereign risk of political corruption to a country or state. This is a major flaw in the framing of the bill and illustrates the inadequacy and weakness inherent within these sections.

5 UN Office on Drugs and Crime (2004) United Nations Convention Against Corruption. https: / /www.unodc org/documents/treaties/UNCAC/Publications/Convention/08-50026_E.pdf (accessed on 4 December 2021). 


\subsubsection{Bifurcation and Creation of Public Sector Classes}

The bill stratifies Commonwealth officials into different classes. This is manifested in the bifurcated nature of the bill's provisions. Section 3.2 distinguishes, on the one hand, the treatment accorded to politicians and other public sector bureaucrats, and, on the other, that accorded to law enforcement bureaucrats. ${ }^{6}$ Politicians are afforded preferential treatment. Section 3.2 permits investigations of law enforcement officers, but not public officials, for corrupt activities. This is problematic because it imposes a higher standard of accountability over the former, versus the latter group of public officials. This bifurcated, preferential structure is set out below in Figure 2:

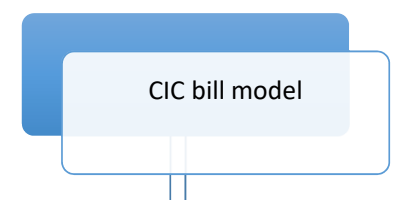

Public sector departments and agencies, parliamentary departments, statutory agencies, Commonwealth companies and corporations, Commonwealth-funded higher education providers and research bodies, parliamentarians (publiclyelected officials) and staff
Public sector division

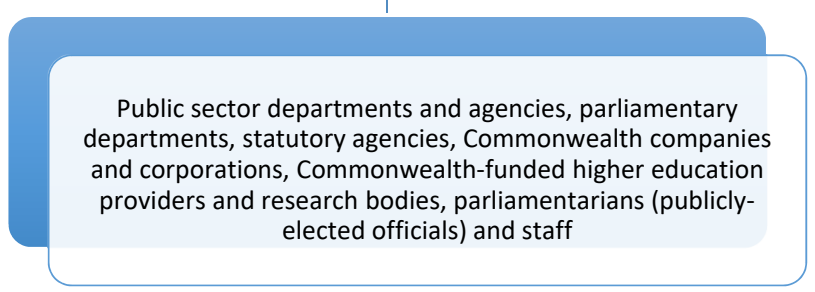

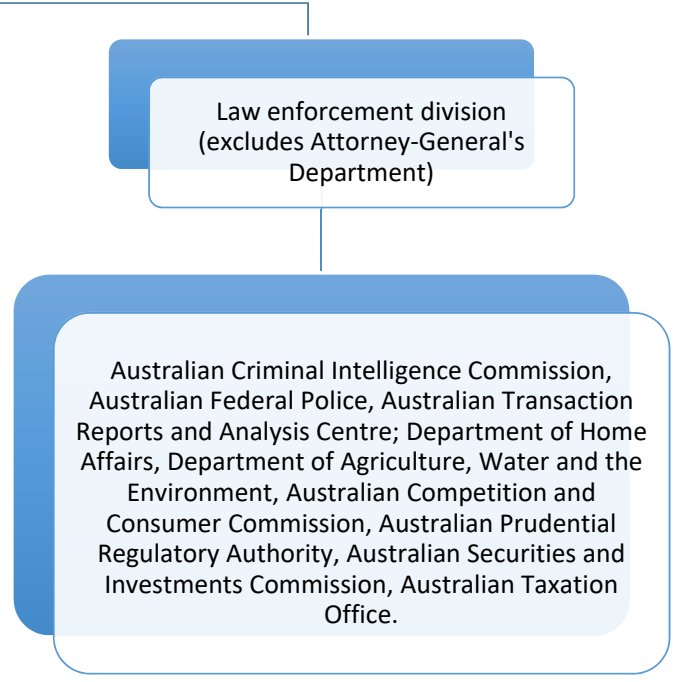

Figure 2. Bifurcation of the proposed CIC bill between public sector and law enforcement division.

For the public sector division, which covers parliamentarians and their staff, the bill "would not receive referrals about those within the public sector integrity division's jurisdiction from the public at large." ${ }^{7}$ In essence, public officials would be protected from complaints lodged by citizens, thus avoiding public scrutiny of the activities of public sector officials.

Section 3 of the bill exposes law enforcement officers, but not other public officials, to the risk of investigations for corrupt activities. This is an issue because it does not impose uniform accountability across all groups and classes of public servants. Section $\mathbf{3}$ states that a member of law enforcement may be referred to the Integrity Commissioner. However, a public sector official can only be referred if the official has also committed a "listed offence" in violation of a Commonwealth law. Members of the law enforcement division are subject to public hearings, but members of the public sector division are not:

Hearings may be held in public when dealing with law enforcement corruption issues, but not when dealing with other corruption issues. (CIC Bill, Section 3).

The issues outlined above led the President of the Australian Federal Police Association, Alex Caruana, to describe the bill as:

6 Attorney General's Department (2020) Commonwealth Integrity Commission Fact Sheet. https:/ / www.ag.gov $\mathrm{au} /$ sites/default/files /2020-11/Commonwealth\%20Integrity\%20Commission\%20Fact\%20Sheet.pdf (accessed on 4 December 2021).

7 Ibid. 
almost like creating a protection racket for their parliamentary mates. It's very much an us and them ... If you're going to create a system for integrity, then it needs to be one rule for everybody. You can't just say 'my mates get this, and everyone else gets that'. It's just not fair. (in Knaus 2020)

Politically corrupt acts by publicly elected officials (politicians) can cause more significant damage to public trust in democracy than acts committed by publicly appointed officers (bureaucrats) due to their access, privileges, and role as leaders entrusted with the public interest. According to the Centre for Public Integrity (2021), not a single civil society organization supports the bifurcated nature of the bill.

\subsubsection{Public Hearings}

Section 99 of the bill states that "a hearing may be conducted in such manner as the Integrity Commissioner thinks fit", and further that in deciding whether a hearing or part of a hearing is to be held in public or in private, the Integrity Commissioner must have regard to the following:

(a) whether evidence that may be given, or a matter that may arise, during the hearing (or that part of the hearing) is of a confidential nature or relates to the commission, or to the alleged or suspected commission, of an offence;

(b) any unfair prejudice to a person's reputation that would be likely to be caused if the hearing (or that part of the hearing) took place in public;

(c) whether it is in the public interest that the hearing (or that part of the hearing) take place in public;

(d) any other relevant matter.

In addition, the fact sheet accompanying the bill states that:

The public sector division would have all the same powers as the law enforcement integrity division with the exception of the ability to hold public hearings or conduct integrity testing (Attorney-General's Department 2020, p. 3).

However, this is a major structural weakness of the bill. The failure to require public hearings when receiving charges involving the public sector division, and the failure to require integrity testing, is problematic when key public appointments are increasingly politicized (Mulgan 2007). It is also inconsistent with the operational success of the NSW ICAC. The NSW ICAC has used public hearings successfully to hold public officials to account (Ackland 2015; Mitchell 2015).

Public hearings have been effective deterrents to corrupt conduct. They promote public confidence in the prosecution of corruption cases. Public hearings reinforce the notion that politically powerful individuals are not above the law and are required to appear before the ICAC when summoned. The proposal to limit public hearings under Section 99 is problematic and highly unusual given the tradition of Australian common law and 'open justice' ( $\mathrm{Ng}$ et al. 2021). Closed hearings, in contrast, do not permit the general public to observe the discharge of these cases. Public hearings promote transparency and help to build public trust that the proceedings are genuine, not sham investigations. According to Checkoway (1981), public hearings build awareness and community participation. Conversely, public hearings expose any biases of the players involved (Emba 2021). For the NSW ICAC, public hearings function as both a corruption preventative measure and to educate the public of what constitutes corruption (Temby 1991).

Public hearings instill confidence that hearings are transparent and fair, and the rule of law is being upheld regardless of a person's position, connection or wealth. Public hearings hold to account the conduct of legal professionals on both sides of an inquiry. Public hearings also elicit information and insights that can be used to promote the public interest, improve public policy, and strengthen public integrity. 


\subsection{NSW ICAC and the Proposed CIC Bill}

When the Morrison Government introduced the proposed CIC bill, there was a strong sentiment that it did not wish to model the federal anti-corruption agency after the NSW ICAC:

It's certainly not a model that we ever consider at a federal level, and I think that's been on display for some time. And you know, you've got to have processes that assume people are innocent before thought to be guilty and that is a real problem. So it's not a model that we've ever contemplated going at a federal level. And, you know, we have a set of arrangements at a federal level that can be built upon, but certainly not going down that path in New South Wales.-Prime Minister Scott Morrison (2021)

The Morrison government rejected the NSW ICAC model despite its proven track record. There are many cases that NSW ICAC has prosecuted successfully. In 2014, NSW ICAC found against the Labor MP and party powerbroker Edward Obeid exposing the misuse of his public office to promote the enrichment of his family (McClymont and Besser 2014; NSW ICAC 2014). The Obeid case saw the subsequent fall of the Labor Government and left an indelible stain of corruption that captured party officials in its web. Obeid was sentenced to jail for five years after being found guilty of misconduct in office (Mayers 2019).

Another NSW ICAC case occurred in late 2020 called Operation Keppel. The NSW ICAC recordings published during the public hearings revealed that the partner-former NSW MP Daryl Maguire - of the then NSW Premier sought to use his personal and professional connections by selling access to the Premier and other key players in the NSW Government. As a state MP, Maguire went beyond his official capacity by interfering with Sydney's diplomatic network and converted his publicly funded role into a personal business brokerage role raising sensitive, political sovereign risk. This is a prime example of political corruption involving the manipulation of asymmetrical information and access. Had NSW ICAC not sought to investigate this influence-peddling, Maguire's conduct would have continued.

Operation Keppel shed light on systemic corruption involving political lobbying, undue influence, related party transactions and conflicts of interest (NSW ICAC 2020). In October 2021, the NSW Premier Gladys Berejiklian resigned (NSW Government 2021), the third NSW Premier to resign due to a NSW ICAC investigation.

\subsection{Higher Education}

The inclusion of higher education in the bill (including under Sections 25, 29, 34, 82, $83,107,277,287$ et al.) seeks to ensure and uphold the integrity of university employees. The bill brings Australia's universities under its purview. State ICACs are already imbued with the responsibility to investigate cases of corruption at universities. There have been instances of corruption at universities, especially in the area of procurement (Collins 2008). The results from such investigations have resulted in an increase to the administrative burden for the universities, although they have contributed to strengthening the integrity of the institutions' processes. NSW ICAC's investigation into the university sector has yielded several completed investigative operations. ${ }^{8}$ The bill would unnecessarily duplicate this regulatory role by the state ICACs.

\section{Amending the Proposed CIC Bill}

Several areas of the bill would benefit from further revisions to strengthen the proposed anti-corruption agency.

8 See Operations Gerda, Elgar, Misto and Citrust from the list of NSW ICAC Investigation Reports. https: //www.icac.nsw.gov.au/investigations/investigation-reports (accessed on 4 December 2021). 


\subsection{Amendments to the Bill}

Part 1 Section 3, which defines key terms of the bill, needs to be expanded so that the bill makes explicit the acts that constitute corrupt behavior. Under Part 2, Division 3, there must be a definition of the acts that constitute political corruption (including undue influence). The current definitions of serious and significant corruption in the bill are insufficient. If they are defined by monetary amounts, those amounts may be then characterized and categorized as "petty" or "grand systemic".

Political corruption may be defined as corrupt acts committed by politically elected or politically appointed public officials. A definition of a public official is offered by Article 2 of the UNCAC (see Section 3.1.2) A list and definition of corrupt acts are covered by the UNCAC under Articles 15 to 25 and can be incorporated into the bill.

As Australia is signatory to the UNCAC, in Part 2, Division 1, Section 5 the following terms ought to be included and defined: bribery, conflicts of interest, lobbying, distinctions of political corruption, petty and systemic corruption (to amend serious or significant corruption especially in the wording in Section 51), patronage, politicization, revolving door, undue influence, trading in influence, and the UNCAC.

Hearings should be explicitly defined as "public hearings" to enable the proposed CIC to conduct public hearings. Former High Court Chief Justice Gleeson found, when reviewing NSW ICAC, that public hearings are 'indispensable to the proper functioning' of an integrity commission (Elmas 2020). This would address a major cause of community concern that closed-door hearings would promote kangaroo courts and constitute a "star chamber without oversight" (Lewis 2021; Livingston 2019).

Part 2 Division 3 Section 17 could be simplified so a singular definition covers all Commonwealth officials, elected, or appointed, without respect to their parliamentary affiliation, thereby removing the bifurcated aspect of the bill. In both Part 2 Division 3 Section 19 and Part 4 Division 2, removing the distinction would permit a corruption investigation to occur regardless of the role of the public official. Similarly, in Part 16 Section 277, subsection c, the words "parliamentarian" and "parliament staffer" should be added so the penalty of 7 years imprisonment for concealing corrupt conduct applies uniformly to all public officials. This would remove the class differentiation that privileges public officials who are not in the law enforcement division.

Part 3 Division 1 Section 25, Part 3 Division 3 Section 31 and Part 3 Division 3 Section 32 of the bill could expand the roles, responsibilities, and functions of CIC officials to tackle political conduct that may lead to real or perceived corruption.

Part 4 Division 3 should make all reporting public. This would enhance the transparency of CIC investigations and promote the agency's capacity to serve an educative and public awareness role.

Part 4 Division 4 should remove the term "vexatious complainant," which suggests the bill is anticipating vexatious complainants. Research suggests that people who are motivated to report corruption do not do so out of a vexatious attitude but, instead, a desire to uphold the integrity of the office (Brown et al. 2014). Part 4 Division 4, Sections 67 to 70, discourage whistleblowing instead of embracing supra-institutional complaints as catalysts to organizational change triggered by organizational wrongdoing (Ceva and Ferretti 2020; Mesmer-Magnus and Viswesvaran 2005). Part 14 Section 269, complements Part 4 as it imposes a requirement to maintain confidentiality on persons who receive information about corruption investigations. This section discourages whistleblowing and public disclosure even though disclosures are presumed to be made honestly and reasonably to protect the public interest (Australian Law Reform Commission 2010). These sections of the bill are misaligned with international instruments protecting whistleblowers, including Article 33 of the UNCAC (Kafteranis 2021). Australia once led the way when it came to whistleblower protections but it now reluctantly follows rather than leads (Pender and Browne 2021; Tobin 2020). A promising model Australia can follow is the US Securities and Exchange Commission (SEC) Office of the Whistleblower. The office was established to protect whistleblowers and promote public and institutional confidence 
in the integrity of the financial sector. The SEC whistleblowing structure, polices and processes reward whistleblowers, rather than punish them. ${ }^{9}$

Parts 5 and 6 require that the proposed Integrity Commissioner inform the target of the corruption investigation that they are indeed under investigation. This potentially serves to tip-off the target and gives the target opportunities to destroy evidence and evade or circumvent formal procedures. Informing anti-corruption investigation targets in this manner may yield unintended consequences as examples overseas have shown (Adut 2004). The proposal to inform targets seems to be part of a broader regulatory trend in Australia towards reifying co-regulation where the administration and enforcement of regulatory obligations occur in collaboration with those being regulated, as demonstrated by the findings of the Banking Royal Commission (Gilligan 2018).

The proposal in Part 8, Division 2 to omit public hearings undermines the purpose of a public integrity body. Part 8, Division 3, Section 136, subsections 3, 4 and 5, suggest that cases involving the Australian military should not be included within the scope of the proposed CIC's anti-corruption investigations. However, military capital equipment expenditures are amongst the very largest public expenditures in Australia with the Department of Defence procurement making up two-thirds of total federal procurement in 2018-2019 (Brangwin and Watt 2019; Transparency International Australia 2020). The catalyst for the passage of the UK Bribery Act 2010 was a case involving BAE Systems bribery of Saudi Arabian officials (Trautman and Altenbaumer-Price 2013). In October 2021, the Morrison Government's decision to break its submarine contract with France negatively impacted its bilateral relationship with the country:

President Macron recalled that Australia's unilateral decision to scale back the French-Australian strategic partnership by putting an end to the ocean-class submarine programme in favour of another as-yet unspecified project broke the relationship of trust between our two countries (Elysée Palace 2021).

This submarine decision, in addition to Australia's procurement of joint strike fighter35 (Layton 2019), indicates that more transparency, not less, is required in the scrutiny of military contracts and defense procurement to deter corruption and improve governance in this sector of government (Gupta et al. 2001).

The limits on public reporting imposed on CIC investigations in Part 9, Division 2 hinder transparency. In particular, the Integrity Commissioner is required to achieve an appropriate balance between the public interest and "the prejudicial consequences that might result from including the information in the report." In contrast, public reporting would promote and enhance trust that the investigative process is not being compromised by vested interests. Section 178 (12) also states that a report must not include an opinion or finding:

(a) about whether a particular person engaged in corrupt conduct; or

(b) about corruption by, or the integrity of, a particular person.

This section removes the public interest disclosure of a corruption investigation if the person was found to have engaged in corrupt conduct.

Part 10 Section 190 states that the CIC must notify its Minister if there is any investigation into corruption within the CIC. To remove any notion of impropriety or conflict, a better approach is to allow corruption investigations within the CIC to be delegated to the Inspector General (by expanding its powers under Part 12 Division 2 Section 231), the Governor-General (as the position is already involved in Part 11 Division 1) or the High Court Chief Justice as the context of the corrupt conduct applies. By way of comparison, NSW ICAC is accountable to a NSW parliamentary committee and the Inspector of NSW ICAC. The NSW Supreme Court also has statutory jurisdiction and supervision of NSW ICAC (NSW ICAC 2019).

9 US SEC Office of the Whistleblower. https:/ / www.sec.gov/whistleblower (accessed on 4 December 2021). 
Part 11, Division 3 Section 225 subsection (g) states "a person referred to in section whose services are made available to the Integrity Commissioner;" This would permit MPs to influence the appointment of officers to the CIC and creates the possibility that unqualified individuals could be appointed, facilitating politicization and political appointments to the proposed CIC. The politicization issue is also raised in Part 12 Divisions 1 to 3. Minimizing political appointments enhances meritocracy, while the opposite promotes abuse of power and corruption (Haynie 1998).

Part 14 could incorporate public hearings across both divisions as the bill only deals with public hearings in the law enforcement division. This addresses both the concern over public hearings and the bifurcation of public officials.

Part 15 Section 270 gives the Attorney-General the ability to withhold the release of information on grounds that are deemed in the public interest. The Attorney-General of Australia is an elected member of parliament, whereas the Integrity Commissioner is an appointed public officer. This gives too much power to the Attorney-General to intervene and provides discretion to not release information to the Integrity Commissioner. It enhances the Attorney-General's discretionary powers to stymie investigations that are political and/or personally detrimental and gives the office holder the authority to conceal the existence of a corruption investigation. This section facilitates the politicization of the office of the Attorney-General and undermines the independence of the processes and operations of an anti-corruption agency.

\subsection{Other Areas of Politically Corrupt Behavior}

There are four other areas of behavior that may induce corrupt conduct that are pertinent in the Australian environment and have not been addressed in the bill. They are the revolving door, political donations, lobbying and bribery. These areas are nominally concerned with the interface between the public and private sector.

\subsubsection{Revolving Door}

The "revolving door" refers to the practice where a public servant secures employment at a private firm that the public servant previously supervised. The revolving door is a promise made whilst in public office but not enacted until after the office. It may be viewed as a delayed bribe (Colignon and Usui 2003). This introduces the possibility that the public servant would favor private entities that would potentially employ the public servant (Schneider 1993), creating fundamental conflicts of interest and economic distortions due to the market for bureaucratic capital (Brezis 2017). Furthermore, private and political elite networks with interlocking directorates suggest collusion where meritocracy is brushed aside in favor of political connections (Buch-Hansen 2014).

In Australia, the revolving door, involving former publicly elected officials, has impacted public policy in the areas of banking, defense, climate change, health and aged care, and the gambling sector (Robertson et al. 2019). The Bergin Inquiry (2021) Report on Crown Casino highlighted the revolving door of public officials when the former Deputy Leader of the Senate, Helen Coonan, the former Chief Health Officer John Horvath, and former Finance and Health Secretary Jane Halton were appointed as Chair and directors, respectively, to this gambling company. Other notable revolving door participants include former Deputy Prime Minister Mark Vaile who became Chair of Whitehaven Coal; former Treasurer Peter Costello to Chair, Nine Entertainment; former Health Minister Nicola Roxon to Chair, BUPA; former Resources Minister Martin Ferguson who became Chair of the advisory board to the petroleum lobby group, Australian Petroleum Production and Exploration Association; former Secretary to the Prime Minister and Cabinet Peter Shergold to Chair, Opal Aged Care; former Secretary of the Treasury Ken Henry to Chair, National Australia Bank; and former Reserve Bank of Australia Governor Glenn Stevens to Chair, Macquarie Bank. In 2019, a Senate Inquiry briefly looked at the revolving door compliance of former ministers (Senate Standing Committee on Finance and Public Administration 2019). 
UNCAC-related provisions regarding the revolving door exist in Article 18 (trading in influence), Article 19 (abuse of functions) and Article 23 (acts of private sector corruption). In the UK, USA and Canada, there are already revolving door bans (see Table 2 in McKeown 2014). Known as pantouflage in France, the revolving door attracts criminal penalties in that jurisdiction. France addresses the revolving door through Article 432-11 to $432-13$ in the French penal code preventing movement, punishable by three years' imprisonment and a fine. ${ }^{10}$ The French legislation covers breaches of public duty, passive corruption, trading in influence and illegal taking of interests such as interrelated party transactions with a company that will ex-post facto provide employment. No such financial penalties, bans or deterrence exist in Australia; thus, the country falls short of international best practice in this regard.

\subsubsection{Political Donations}

Political donations involve the purchase of influence, access, and policy. Similar to the issues that emerge from the revolving door, political donations bypass the formal public institutional channels of policy formulation and implementation. Political donations are an insidious form of political corruption as they provide access to those with the wealth to influence public policy formulation and bypass the democratic process (Edwards 2017).

In the Australian environment, political donations have become controversial, as companies that are political donors are perceived to have been rewarded with government contracts with little regard to the merits of the organization. For example, a AU $\$ 420 \mathrm{M}$ contract was awarded through an opaque tendering process to the Paladin Group, a littleknown security contractor founded by former Australian Army soldier Craig Thrupp and his business partner Ian Stewart. Paladin was headquartered at a beach shack on Kangaroo Island (Beech 2019), suggesting a lack of capacity to perform the contracted work. The aforementioned gambling industry is also a massive political donor (Johnson and Livingstone 2021).

During the COVID-19 pandemic, political donors such as Sonic Healthcare and Aspen Medical received substantial government contracts to roll out the federal COVID-19 vaccination as part of the Department of Health's surge workforce for recipients in the high priority aged care category (Lucas 2021). However, the results were distressing, involving major outbreaks, delays, and the deployment of unqualified personnel (Knaus 2021b; Sinanidis 2021). This raises questions regarding the performance of these contracts and the influence of political donations in the disbursement of such contracts.

In Australia, the source of donations and lack of real-time transparency of political donations remain a concern (Edwards 2017; Leong and Hazelton 2017). A 2019 bill, the Commonwealth Electoral Amendment (Real Time Disclosure of Political Donations) did not pass which would have addressed this issue under the aegis of the election administration body, the Australian Electoral Commission (AEC).

A 2019 Australian study by Cameron and Wynter (2019) found voters perceived conservative parties in government raised greater concerns over the role of political donations made by vested interests. These concerns are acute in a political environment where campaign finance transparency is nascent. There are many sectors in Australia where political donations have become de rigeur amongst Australian companies and their director networks (Ramsay et al. 2001). However, political donations by companies remain a contested issue for shareholder activists as to whether this cost of doing business is an appropriate use of company funds to influence and capture governments (Lu et al. 2016). On a global level, the International Corporate Governance Network (ICGN) whose membership consist of institutional investors with some USD 59 trillion of assets under management (ICGN 2021), has cautioned the use of both lobbying and political donations by the private sector, as they create

10 See Legifrance https:/ / www.legifrance.gouv.fr/codes/article_lc/LEGIARTI000033912762/ (accessed on 4 December 2021). 
ethical lapses or disproportionate influence by corporations [and] can create distortions that can impact not only civil society, but also the efficient operation of markets and the interests of investors. (ICGN 2017, p. 4)

Regarding the recipient of such donations, other countries impose explicit oversight and provisions addressing the business affairs of politicians and public officials to assess whether their political or public position has served to enrich them through forms of grey corruption (OECD 2011). Unexplained wealth orders are useful tools to "investigate/prosecute the otherwise very difficult offences of corruption and bribery" (Bartels 2010, p. 4). Unexplained wealth orders are an operational application of the UNCAC Article 20 regarding illicit enrichment. Another tool is the use of lifestyle audits or lifestyle checks to determine if public officials are living beyond the means provided by their public salaries (France 2021).

Western Australia's Corruption and Crime Commission utilizes unexplained wealth orders under Section 21AD of its Corruption Crime and Misconduct Act of 2003. ${ }^{11}$ This type of wealth order could be incorporated into the CIC bill to discourage federal public officials from engaging in improper conduct that results in unexplained wealth. This type of unexplained wealth order could, for example, have discouraged former Federal Attorney-General Christian Porter from failing to declare the donors to his legal fund, involving a defamation case. ${ }^{12}$ The Porter case illustrates gaps in regulation regarding political donations and campaign finance.

\subsubsection{Lobbying}

In Australia, political lobbying is professionalized (Halpin and Warhurst 2015). Similar to the revolving door, former ministers and government bureaucrats have joined lobbying firms.

These firms act on behalf of clients receiving government contracts. This introduces the possibility of a conflict of interest, i.e., ministers and bureaucrats may act in ways that favor preferred clients as a means of ingratiating themselves with lobbying firms who may potentially hire them as lobbyists. In essence, ministers and bureaucrats may use their official positions to obtain lucrative post-government employment. This amounts to trading in influence and position (Miller and Dinan 2008). Personal financial self-interest is set against the interests of the public and civil society. Even at its most benign, these types of behavior fuel distrust by the public in both business and government elites.

While there is an existing lobbying code of conduct (Attorney-General's Department 2019), the lack of either civil or criminal penalties mean this code is an aspirational guide to ideal post-public office behavior rather than a deterrence. The case of former Defence Minister Christopher Pyne's and his former chief of staff's establishment of a defense industry lobbying firm (Knaus 2021a) is emblematic of this problem. Part 11 Division 1 Section 217 and Part 12 Division 4 Section 249 of the proposed CIC bill could be expanded to include lobbying and revolving door prohibitions.

\subsubsection{Bribery}

On the issue of bribery, Australia lags behind in its implementation of the OECD Convention on Combating Bribery of Foreign Public Officials in International Business Transactions, and the OECD 2009 Recommendation of the Council for Further Combating Bribery of Foreign Public Officials in International Business Transactions. The OECD Working Group on Bribery is concerned "about the continued low level of foreign bribery enforcement in Australia given the size of Australia's economy and the high-risk regions and sectors in which its companies operate." (OECD Working Group on Bribery 2019, p. 3).

11 WA Corruption, Crime and Misconduct Act (2003) section 21AD. http:/ / www5.austlii.edu.au/au/legis/wa/ consol_act/ccama2003330/s21ad.html (accessed on 4 December 2021).

12 According to the Prime Minister Scott Morrison, Porter's fund is "a blind trust. He cannot disclose to me who his donors are." Press Conference, 19 September 2021. https:/ / www.pm.gov.au/media / press-conferencekirribilli-nsw-8 (accessed on 4 December 2021) 
The Working Group has suggested improvements in current legislation and Australia has several Commonwealth legislation that address specific sections of the Convention. Nevertheless, there is no overarching federal legislation to deal with bribery that is available despite the cases of the Australian Wheat Board, Securency and Note Printing Australia, and Lifese (Barker 2019). On this point, the UK Bribery Act 2010 might be a useful legislative model for Australia to follow. ${ }^{13}$

In addition, on a practical level to address this form of corruption, a smart phone application similar to the one in Malaysia where the public can report bribery could be introduced ${ }^{14}$. In India, there is an activist citizen-run website called "I paid a bribe"15 to highlight petty corruption, while a Romanian website allows public reporting of the value of the bribe market in accessing public services. ${ }^{16}$

\subsection{Alternative Federal ICAC Bills}

There were two other bills that were introduced in the 46th Parliament for a federal anti-corruption agency. The first was a private member's bill, the Australian Federal Integrity Commission (2020) ${ }^{17}$ bill proposed by House of Representatives independent MP Helen Haines which has the support of civil society organization Transparency International Australia. However, it did not pass. The second was the National Integrity Commission Bill (2018) No. $2^{18}$ which was proposed by the Greens Senator Larissa Waters. The latter passed the Senate and, at the time of writing, has moved to the House of Representatives for debate. Both bills propose stronger independent powers than the CIC bill, incorporating public hearings and whistleblower protection commissioners.

The arduous legislative journey to establish an Australian federal anti-corruption agency mirrors other countries' establishment of anti-corruption commissions (dela Rama and Lester 2019; Heilbrunn 2004; Schutte 2012). The inertia in the passage of the three bills reflects political discord and intransigence. The reluctant establishment of an anticorruption commission at the federal level in Australia reflects the push-pull forces of existing influences and powers in the country-pulled largely by civil society (Transparency International Australia 2020); and pushed back by politicians whose behavior and interests would be scrutinized by any proposed integrity commission. At the time of writing, the Morrison Government's CIC bill has not been introduced to Parliament in its current form.

\section{The APUNCAC}

The preceding analysis outlined key issues of political corruption in Australia and how they are (and are not) addressed in the proposed CIC bill. Australia could, and should, do more to fight corruption. For a country that has historically and enthusiastically supported the multilateral regime (Kirby 2009; Lester and dela Rama 2018), what models could Australia draw upon? How might Australia align its legal regime with recent international developments in anti-corruption?

The Anticorruption Protocol to the UN Convention Against Corruption (APUNCAC) is a 200-page draft international treaty that seeks to fill existing gaps in the UNCAC and fulfill the promise of the UNCAC to fight corruption ${ }^{19}$. The APUNCAC seeks to fill gaps in existing international conventions and domestic anticorruption law. The APUNCAC

13 UK Bribery Act (2010). https://www.legislation.gov.uk/ukpga/2010/23/pdfs/ukpga_20100023_en.pdf (accessed on 4 December 2021)

14 Malaysian Anti-Corruption Commission—Report Corruption https://www.sprm.gov.my/index.php?page id $=100 \&$ language $=$ en (accessed on 4 December 2021)

15 I Paid a Bribe: http:/ / www.ipaidabribe.com (accessed on 4 December 2021).

16 Piata de Spaga https:/ / www.piatadespaga.ro (accessed on 4 December 2021)

17 https://www.aph.gov.au/Parliamentary_Business/Bills_Legislation/Bills_Search_Results/Result?bId=r6 597 (accessed on 4 December 2021).

18 https://www.aph.gov.au/Parliamentary_Business/Bills_LEGislation/Bills_Search_Results/Result?bId=s1 154 (accessed on 4 December 2021).

19 Yeh, Stuart S., "Anticorruption Protocol to the United Nations Convention against Corruption." Accessed 22 July 2021. http://tinyurl.com/y6bkpott (accessed on 4 December 2021). 
incorporates numerous provisions designed to fight corruption within, and across, the borders of potential States Parties to the Convention. The APUNCAC seeks to establish an International Commission against Corruption (ICAC), involving a body of UN anticorruption investigators funded and supported by the UN, with strong powers to investigate charges of corruption and refer cases to dedicated domestic anticorruption courts. The APUNCAC includes numerous provisions designed to deter conflicts of interest, corruption related to campaign finance and lobbying, and corruption in public procurement. The APUNCAC represents an international trend towards more forceful measures and empowering institutions to fight corruption. The APUNCAC offers an international best practice model for Australia. It is useful, therefore, to consider the implications of the APUNCAC regarding Australia's progress in developing strong institutions to fight corruption. Certain provisions of the APUNCAC are of special relevance in addressing political corruption in Australia.

Article 8 would establish dedicated domestic anticorruption courts. This article offers an exemplar for UN Member States that have yet to establish specific anti-corruption courts.

Article 10, regarding Obstruction of Justice. Section 1 states that a report would be published online by Transparency International once a corruption investigation has been filed by UN inspectors. This addresses the fundamental transparency requirements of anti-corruption investigations.

Article 14 on Censure states that if a UN investigation is obstructed, a UN inspector may file a request for censure. The World Bank or IMF would implement sanctions.

Article 19 Financial System Safeguards and Articles 21, 22, 26 and 40. Article 19 would establish an International Financial Crimes Enforcement Network (FINCEN) that would address issues of money laundering and seek to improve transparency and accountability for financial crimes. The establishment of FINCEN, modelled on the US Treasury Department's FinCEN, would promote international cooperation to address loopholes in the international financial system that permit criminals to hide illicit funds in offshore havens. Article 19 could, for example, have been applied to investigate the case of Westpac Bank, an Australian bank and financial services provider which was fined AU\$1.3B for committing over 23 million breaches of anti-money laundering regulations (Janda 2020).

Articles 24, 29 and 36 impose requirements related to casino recordkeeping. These requirements would address issues related to Australia's gambling industry illustrated, for example, by the case of Crown Casino (Bavas 2021), and the associated Bergin Inquiry (2021).

Article 43 lists prohibited interests and conduct by public officials. In comparison to the proposed CIC Bill, this Article represents a more comprehensive treatise regarding the proper behavior of a public servant. However, with respect to revolving door issues under this Article, clauses $\mathbf{2 3}$ and $\mathbf{2 4}$ take a less rigorous approach compared to the revolving door legislation covered by the French criminal code.

Article 44 on Reporting and Disclosure of Interests could be adapted and incorporated into Australia's CIC bill:

No public servant shall attempt to influence the course of any proposed legislation in the legislative body of the government without publicly disclosing on the official records of the legislative body the nature and extent of any direct or indirect financial or other private interest the public servant may have in such legislation.

This would address conflicts of interest.

Article 46 provides Penalties on Gifts by Lobbyists and extends this to family members and close personal friends. Entertainment expenses, gifts of wine and tickets to events would come under scrutiny under this article and would discourage the quid pro quo relationships that have drawn scrutiny in Australia (Prenzler et al. 2018). This provision could be adapted in Australia so that the gift or promise of employment to a former public official by a lobby firm would be covered under this article. The revolving door phenomenon in 
Australia demonstrates that both employed and elected public sector officials find lucrative employment after their public service (Knaus 2021a; Robertson et al. 2019).

Article 49 on Facilitation Payments deals with 'bread-and-butter' bribery and is already addressed in some form across disparate pieces of Commonwealth legislation. On the matter of more serious forms of bribery such as political donations, Article 68 addresses Campaign Reform, imposing limits on political donations. This is pertinent to Australia's situation as outlined in Section 4.2.2 above.

Article 50 regarding Transfer Pricing recognizes the negative economic impact of tax avoidance and tax minimization strategies deployed by companies on their host countries. This Article also requires member states to conform to OECD Transfer Pricing Guidelines. In Australia, several players in certain industrial sectors-from oil and gas, to aged care and technology - have engaged in these strategies to reduce tax revenues to government. Prime examples include Chevron and Google's Australian subsidiaries which engaged in transfer pricing activities to minimize their tax obligations in the country (Cooper 2017; Butler and Nicholas 2021). Transfer pricing has a socio-economically detrimental impact on the host nation affected by such activities (Mehafdi 2000). Article 50 offers a model for Australia and may improve standards in this area as it recognizes that transfer pricing is an issue that must be tackled globally.

Article 51 on Whistleblowing recognizes the need for an avenue where any member of the public could submit information through a website to support allegations of corruption. This Article provides a constructive way for whistleblowers to speak up in the face of perceived and injustice. Recognizing the work of whistleblowers and protecting them is fundamental to anti-corruption efforts. The APUNCAC's whistleblower provisions set higher standards and expectations of behavior as opposed to its current treatment in the proposed CIC bill. ${ }^{20}$

Article 58 on Public Procurement provides an extensive, more transparent, rulesbased approach regarding the expected standards of behavior between bidder and contractor when it comes to government contracts. It seeks to ensure the independence and integrity of the government body and officials that are disbursing such contracts. The incorporation of Article 58 into the proposed CIC bill would address corruption in Australia's government contracts system where limited tenders have created a layer of opacity regarding what should be an open and transparent process that awards government contracts on the basis of merit and not on the basis of political connections or political donations. The presence of former public servants and former politicians on company boards that are then awarded lucrative government contracts underlines the problems of Australia's political corruption in the procurement process.

Finally, Article 73 on Implementation denotes a timeline for the ratification of the APUNCAC by member states. This imposes temporal deadlines.

\section{The International Anti-Corruption Court (IACC)}

Senior US District Court Judge Mark Wolf proposed the establishment of an International Anti-Corruption Court (IACC) (Wolf 2018). The IACC could serve, along with the APUNCAC's dedicated domestic anticorruption courts, as venues to prosecute cases of corruption. Yeh (2021) proposed that Wolf's IACC could perhaps serve as an international supreme court in cases of grand corruption, if the APUNCAC's dedicated domestic anticorruption courts are prevented from prosecuting powerful political leaders. The proposed IACC would rely upon the concept of universal jurisdiction to assume authority in cases where powerful elites escape domestic prosecution (Haynie 1998).

While criticized by some jurists as ambitious, there is some merit in considering how the court could conceivably operate. The UN Office on Drugs and Crime could offer

20 See pp. 32-33 of the Law Council of Australia's (2021). Submission to the CIC draft consultation on whistleblower protections. https:/ / www.lawcouncil.asn.au/publicassets /61c2c03e-ce74-eb11-9439-005056be1 3b5/3966\%20-\%20Commonwealth\%20Integrity\%20Commission\%20consultation\%20draft.pdf (accessed on 4 December 2021) 
extensive technical advice, experience, and knowledge in establishing the IACC. It was also highlighted at the Summit for Democracy and the UNCAC COSP9 (see next section) that public prosecutors in some countries face an arduous battle when pursuing cases against the politically powerful in their home countries.

In addition to the personal threats made against the lives of those involved in prosecuting an anti-corruption case, the technical issues of transnational recovery of public assets can be overwhelming to a judiciary not resourced with the requisite knowledge or financial expertise in money laundering. They can also be limited by jurisdiction or lack of international cooperation; and/or cowed by the executive branch of government. For example, the civil society NGO, UNCAC Coalition ${ }^{21}$, has called for a regional court in the African Union (UNCAC Coalition 2021); while both the presidents of Colombia and Peru issued a 2019 joint declaration supporting the establishment of an IACC (Peruvian Ministry of Foreign Relations 2019). ${ }^{22}$

Another possibility is to establish a commercial division within the proposed IACC to address public-to-private and private-to-private sector corruption. This could follow either the HK ICAC or the US SEC models, or commercial dispute resolution bodies such as Singapore's International Arbitration Centre. ${ }^{23}$ The proposed IACC offers yet another institutional model that Australia might adopt on a national level.

\section{The 2021 UN General Assembly Special Session (UNGASS) on Corruption and the 9th Conference of States Parties to the UNCAC (COSP9)}

In 2021, two events advanced international cooperation to investigate corruption and promote anti-corruption efforts. Multilateral cooperation in addressing corruption was highlighted in a UN General Assembly Special Session (shortened to UNGASS 2021) held from the 2 nd to the 4 th of June 2021, the first such session on corruption. The political declaration adopted by the General Assembly highlighted the written commitment of UN Member States to fight corruption:

Our common commitment to effectively addressing challenges and implementing measures to prevent and combat corruption and strengthen international cooperation (UN General Assembly 2021).

The main sessions and side sessions at UNGASS 2021 emphasized the importance of civil society, the freedom of the press and stronger whistleblower protections for all member states to tackle corruption in their home countries. UNGASS 2021 provided a forum to share member states' experiences of corruption, including COVID-19 failures in the areas of vaccine procurement, supply, and delivery.

A side session hosted by the OECD and law enforcement bodies highlighted Thailand's experience and recounted the effectiveness of Thailand's National Anti-Corruption Commission (NACC) and its advice to the Thai government regarding sectors prone to corruption during the pandemic and how other public agencies may address such corrupt conduct. UNGASS 2021 emphasized the demand and the continued need to address corruption at all levels of government.

21 UNCAC Coalition Submission (2021) to the 9th Session of the of the UNCAC Conference of the States Parties-Anti-Corruption Priorities in the Sub-Saharan African Region, 26 November. https://www. unodc.org/documents / treaties/UNCAC/COSP/session9/NGO/CAC-COSP-2021-NGO-28.pdf (accessed on 4 December 2021).

22 From paragraph 6 of the declaration: "Reiteraron el compromiso de los gobiernos del Perú y Colombia en la lucha frontal contra la corrupción, para el resguardo de la institucionalidad democrática y el desarrollo de los pueblos; que se materializa en la convocatoria conjunta para celebrar un período extraordinario de sesiones de la Asamblea General de Naciones Unidas, en el primer semestre de 2021, con el objetivo de adoptar acciones concretas para prevenir y combatir la corrupción, así como para fortalecer la cooperación internacional en la materia, incluyendo el estudio de la propuesta colombiana de crear un mecanismo judicial supranacional." (emphasis added; final clause is "to create a supranational court").

23 Singapore International Arbitration Centre. https: / /www.siac.org.sg/ (accessed on 4 December 2021). 
Continuing the work from UNGASS 2021, the 9th Conference of States Parties (shortened to COSP9) to the UNCAC ${ }^{24}$, was held from the 13th to 17th December 2021 in Sharm el-Sheikh, Egypt to review the implementation of the Convention, asset recovery, international anti-corruption cooperation, corruption prevention and technical assistance (UN Office of Drugs and Crime 2021).

The conference adopted eight resolutions by consensus. These resolutions covered international cooperation over preventing corruption during periods of crises (the Sharm el-Sheikh Declaration), further collaboration between institutions, beneficial ownership transparency on the identities of holders of shell companies, blind trusts and the like, to help with asset recovery such as the World Bank's STAR initiative ${ }^{25}$, anti-corruption law enforcement cooperation through UNODC's GLOBE Network ${ }^{26}$, anti-corruption education, and further follow-ups to previous declarations (Abu Dhabi and Marrakech) including the UNGASS $^{27}$

Side sessions at COSP9 included a focus on the role of campaign finance in elections by the International Federation for Electoral Systems (IFES) ${ }^{28}$, government and public contracting transparency initiatives from the Open Contracting Partnership ${ }^{29}$, and inadequacies within some national jurisdictions that undermine protection of public prosecutors in pursuit of asset recovery of public monies from powerful elites.

Notably, in the week before COSP9, the US Biden Administration's Summit for Democracy highlighted the national security threat posed by corruption and kleptocracy to democracy (White House 2021) ${ }^{30}$. One civil society side event highlighted the work of a UN working group report on business, corruption and impact on human rights (UN Human Rights Office of the High Commissioner 2020); while one business side event highlighted the deterrent role corrupt environments present to potential private sector bidders on government contracts.

While there will be continued challenges in addressing the adaptive nature of corruption, UNGASS 2021 and the UNCAC COSP9 demonstrate the commitment by UN Member States to address this challenge. They highlight the progress and action being made at the international level to mitigate and address the destructive effects of corruption.

\section{Concluding Remarks}

There is a need for strong legislation, both domestic and international, to fight corruption. While the proposed CIC bill seeks to address corruption, and there are international conventions that exist to fight corruption, the persistence of corruption suggests that there is a need for more aggressive measures. There is a fundamental institutional requirement to support Australia's domestic anticorruption initiative by incorporating international anti-corruption measures from the UNCAC and the APUNCAC. There is momentum on the multilateral level to address corruption, represented by UNGASS 2021 and the UNCAC COSP9, and to implement existing agreements domestically. In 2022, Australia, with Indonesia, are co-chairs and co-hosts of the G20 Anti-Corruption Working Group. ${ }^{31}$ Tackling the problems of corruption and promoting anti-corruption efforts are here to stay.

24 UN Office of Drugs and Crime-Conference of the States Parties to the UN Convention Against Corruption. https://www.unodc.org/unodc/en/corruption/COSP/conference-of-the-states-parties.html (accessed on 4 December 2021).

25 World Bank-Stolen Asset Recovery Initiative. https://star.worldbank.org (accessed on 11 January 2022).

26 UN Office of Drugs and Crime-Global operational network of anti-corruption law enforcement authorities. https: //globenetwork.unodc.org (accessed on 4 December 2021).

27 UNCAC Coalition-Ninth Session of the UNCAC Conference of States Parties. https: / / uncaccoalition.org/uncacbodies / conference-of-states-parties / cosp9/ (accessed on 4 December 2021).

28 https://www.ifes.org (accessed on 4 December 2021).

29 https://www.open-contracting.org (accessed on 4 December 2021).

30 https://www.state.gov/summit-for-democracy/ (accessed on 4 December 2021).

31 UN Office of Drugs and Crime-G20 Anti-Corruption Working Group. https: / /www.unodc.org/unodc/en/ corruption/g20-anti-corruption-resources/by-thematic-area.html (accessedon 11 January 2022). 
Since 2012, Australia has slipped compared to peers on Transparency International's Corruption Perceptions Index. Additionally, the perception of private influence has only grown and become normalized through a series of government expenditure scandals and questionable actions. This article has critiqued the proposed Australian CIC and offered suggestions to improve integrity and promote transparency and accountability within the proposed agency so that it can deal with extant corruption free from perceived politicization or undue influence. The suggestions seek to strengthen, both internally and externally, the remit and operation of the proposed institution to handle political corruption in Australia.

First, the CIC should deploy a broader conceptualization of corruption, emphasizing the need for integrity in all public and private sector interactions involving all elected and appointed public officials. Second, the provisions that shield public officers, not involved in law enforcement, from corruption investigations should be eliminated. Third, the CIC should be empowered to convene public hearings to shine a bright light where it is needed to promote a healthy moral climate within Australia's public institutions.

A fundamental premise underlying the rule of law is that all must be treated equally before the law. The political and administrative privileges of Australia's elected and nonelected public officials expose them to the risk of corruption. The proposed CIC bill should be amended to set the same standards defining conflicts of interest for public servants and elected officials that are articulated in the APUNCAC.

Externally, a range of other reforms are needed to further strengthen the national integrity ecosystem within Australia, including reforms related to private sector interactions such as political donations, the revolving door, lobbying and the full implementation of the OECD anti-bribery convention. Transparency initiatives on campaign finance and beneficial ownership are already available internationally. Notably, France-in addition to its anticorruption agency ${ }^{32}$ - has a public agency which directly addresses conflicts of interest involving public officials and lobbying through the High Authority for Transparency in Public Life (HATVP) $)^{33}$.

The private sector in Australia also has a fundamental role to play to ensure it does not contribute to undermining and weakening the integrity of the country's public institutions by capturing its public officials. Corruption adds to the cost of business transactions, creates inefficient markets, deters ethical actors, and generates an uneven playing field (dela Rama and Rowley 2017). Institutional investors and major stockholders must exercise their fiduciary duties to limit and deter corrupt conduct in companies they own. Adopting the APUNCAC's provisions regarding lobbying, facilitation payments/bribery, whistleblowing, transfer pricing and public procurement, and other related matters, would further strengthen the Australian integrity ecosystem.

A properly funded and independent CIC that follows the principles set out by the APUNCAC would strengthen the deterrence of corrupt behavior. Corrupt parties would face not only criminal but also common law proceedings, disqualifications, de-registrations, and fines. The CIC's investigative role should be underpinned by a well-resourced program of research, education, and greater community awareness, and ensure that it meets or follows the guidelines set out by the APUNCAC. The financial independence of the CIC should also be guaranteed for the institution to effectively exercise its duties with neither fear nor favor.

The concept and operationalization of an institutionalized integrity commission are recognized by the APUNCAC. Rather than protect the self-interests of the powerful, there is a need to remind them of the limitations of their powers and interests when it comes to their impact on the public interest.

Our framework highlights factors that influence the level of corruption within the political ecosystem and the interconnecting relationships between stakeholders within that ecosystem. It also highlights how grey areas of corruption influence perceptions of

32 https://www.agence-francaise-anticorruption.gouv.fr/fr (accessed on 4 December 2021).

33 https://www.hatvp.fr/en/ (accessed on 4 December 2021). 
trust in democratic institutions. Australia would benefit by aligning and supporting its anticorruption regime with existing international standards and the global trend toward strong measures and institutions to fight corruption. The APUNCAC provides valuable guidance on how a CIC should be formulated and eventually implemented.

A federal anti-corruption agency bill offers an opportunity to promote governance according to liberal democratic principles where there is a level playing field, respect for the rule of law, and where the public interest is not overridden by plutocratic or kleptocratic tendencies. At stake is the legitimacy of government and public perception of the integrity and health of the country's democratic institutions. Australia is a cautionary tale of a country that can easily lose its way when it comes to tackling corruption. A country that was once seen as an exemplar when it comes to anti-corruption initiatives and preventing its many ills, is replete with far too many examples of them. There is a need to pass a robust bill establishing an anti-corruption agency that would align Australia with best practices and international standards, and to demonstrate that Australia is proactive, not reactive, in addressing political corruption.

Author Contributions: Writing—original draft preparation and conceptual framework, M.J.d.R. and M.E.L.; writing-reviewing and editing, M.J.d.R. and W.S. All authors have read and agreed to the published version of the manuscript.

Funding: This research received no external funding.

Institutional Review Board Statement: Not applicable.

Informed Consent Statement: Not applicable.

Data Availability Statement: Not applicable.

Acknowledgments: The authors would like to thank the Special Issue editor Stuart Yeh for his extensive comments regarding the APUNCAC, the two anonymous reviewers whose suggestions have helped refine and clarify this manuscript, and Messi Wang for his help during the review process.

Conflicts of Interest: The authors declare no conflict of interest. The first author was part of the civil society consultation process of the CIC bill conducted by the Australian Government's AttorneyGeneral's Department held on 4 December 2020; and an accredited civil society special observer at UNGASS 2021 and the UNCAC COSP9.

\section{References}

Ackland, Richard. 2015. ICAC has been effective in the fight against corruption in NSW. The Guardian, November 13. Available online: https:/ / www.theguardian.com/australia-news/2015/nov/13/icac-has-been-effective-in-the-fight-against-corruptionin-nsw (accessed on 4 December 2021).

Adut, Ari. 2004. Scandal as norm entrepreneurship strategy: Corruption and the French investigating magistrates. Theory and Society 33: 529-78. [CrossRef]

Anderson, Stephanie. 2016. Political donations down almost $\$ 100 \mathrm{~m}$ in run-up to federal election. ABC News, February 1. Available online: https:/ / www.abc.net.au/news/2016-02-01/political-donations-down-almost-100m/7128866 (accessed on 4 December 2021).

Ashforth, Blake, and Vikas Anand. 2003. The normalisation of corruption in organisations. In Research in Organisational Behaviour. Edited by Barry Staw and Roderick M. Kramer. Amsterdam: Elsevier Science, vol. 25, pp. 1-52.

Attorney-General's Department. 2019. Lobbying Code of Conduct. November 28. Available online: https://www.ag.gov.au/integrity/ publications / lobbying-code-conduct (accessed on 4 December 2021).

Attorney-General's Department. 2020. Commonwealth Integrity Commission. Fact Sheet. November. Available online: https:// www.ag.gov.au/sites/default/files/2020-11/Commonwealth\%20Integrity\%20Commission\%20Fact\%20Sheet.pdf (accessed on 4 December 2021).

Aulby, Hannah. 2017. The Case for a Federal Corruption Watchdog. The Australia Institute. Discussion Paper. August. Available online: https:/ / australiainstitute.org.au/wp-content/uploads/2020/12/P380-Case-for-a-federal-ICAC.pdf (accessed on 4 December 2021).

Australian Law Reform Commission. 2010. Public Interest Disclosure. Available online: https://www.alrc.gov.au/publication/secrecylaws-and-open-government-in-australia-alrc-report-112/7-general-secrecy-offence-exceptions-and-penalties/public-interestdisclosure/ (accessed on 4 December 2021). 
Barker, Cat. 2019. Australia's implementation of the OECD Anti-Bribery Convention. Commonwealth of Australia: Australian Parliamentary Library Research Paper Series. August 28. Available online: https://www.aph.gov.au/About_Parliament/Parliamentary_ Departments/Parliamentary_Library/pubs/rp/rp1920/Anti-BriberyConvention (accessed on 4 December 2021).

Barrett, Nicholas, and Anthony Reuben. 2021. What is going on with government Covid contracts? BBC Reality Check, June 30. Available online: https:/ / www.bbc.com/news/56174954 (accessed on 4 December 2021).

Bartels, Lorana. 2010. Unexplained wealth laws in Australia. Trends and Issues in Crime and Criminal Justice 395: 1-6.

Bavas, Josh. 2021. Influencers live it up at Casino-Less Crown Sydney in Wake of Savage Report. ABC News, March 4. Available online: https:/ / www.abc.net.au/news/2021-03-04/influencers-live-it-up-at-crown-sydney-after-scathing-report/13207746 (accessed on 4 December 2021).

Beech, Alexandra. 2019. Federal Government probed over awarding of Manus Island security contracts to Paladin Group. $A B C$ News, February 18. Available online: https:/ / www.abc.net.au/news/2019-02-18/government-to-be-grilled-over-manus-islandsecurity-contracts/10820268 (accessed on 4 December 2021).

Bell, Stephen, and Andrew Hindmoor. 2014. The structural power of business and the power of ideas: The strange case of the Australian mining tax. New Political Economy 19: 470-86. [CrossRef]

Bergin Inquiry. 2021. Report of the Inquiry under Section 143 of the Casino Control Act 1992 (NSW). dated 1 February 2021 (Volumes One and Two). Sydney: Parliament of NSW. Available online: https://www.parliament.nsw.gov.au/la/papers/Pages/tabled-paperdetails.aspx?pk=79129 (accessed on 4 December 2021).

Brangwin, Nicole, and David Watt. 2019. Defence-Budget Review 2019-20 Index. Available online: https://www.aph.gov.au/ About_Parliament/Parliamentary_Departments/Parliamentary_Library/pubs/rp/BudgetReview201920/Defence (accessed on 4 December 2021).

Brezis, Elise S. 2017. Legal conflicts of interest of the revolving door. Journal of Macroeconomics 52: 175-88. [CrossRef]

Brown, Alexander Jonathan, David Lewis, Richard Moberly, and Wim Vandekerckhove. 2014. International Handbook on Whistleblowing Research. London: Edward Elgar.

Buch-Hansen, Hubert. 2014. Interlocking directorates and collusion: An empirical analysis. International Sociology 29: 249-67. [CrossRef]

Butler, Ben, and Josh Nicholas. 2021. Household names: 168 Australian companies have paid no tax since 2013. The Guardian, December 10. Available online: https: / / www.theguardian.com/australia-news/2021/dec/10/household-names-168-australiancompanies-have-paid-no-tax-since-2013 (accessed on 4 December 2021).

Cameron, Sarah, and Thomas Wynter. 2019. Campaign finance and perceptions of interest group influence in Australia. Political Science 70: 169-88. [CrossRef]

Centre for Public Integrity. 2021. Table 1: Who Supports Key Features of the CIC Draft Exposure Bill from Commonwealth Integrity Consultation: The Government Is the Only Supporter of Its CIC. May. Available online: https://publicintegrity.org.au/wpcontent/uploads/2021/05/Briefing-paper-Govt-only-supporter-of-CIC.pdf (accessed on 4 December 2021).

Ceva, Emanuela, and Maria Paola Ferretti. 2017. Political corruption. Philosophy Compass 12: e12461. [CrossRef]

Ceva, Emanuela, and Maria Paola Ferretti. 2020. Theories of whistleblowing. Philosophy Compass 15: e12642. [CrossRef]

Charles, Stephen. 2020. This country needs a strong National Integrity Commission. Sydney Morning Herald, October 28. Available online: https://www.smh.com.au/national/this-country-needs-a-strong-national-integrity-commission-20201027-p56927.html (accessed on 4 December 2021).

Checkoway, Barry. 1981. The politics of public hearings. Journal of Applied Behavioral Science 17: 566-82. [CrossRef]

Chenoweth, Neil. 2016. 'Destroy ICAC', prosecutor Margaret Cunneen says. Financial Review, February 5. Available online: https: //www.afr.com/companies/professional-services/destroy-icac-prosecutor-margaret-cunneen-says-20160204-gmllll (accessed on 4 December 2021).

Choo, Kim-Kwang Raymond. 2008. Politically-exposed persons (PEPs): Risks and mitigation. Journal of Money Laundering Control 11: 371-87. [CrossRef]

Colignon, Richard A., and Chikako Usui. 2003. Amakudari. New York: Cornell University Press.

Collins, Sarah-Jane. 2008. Football legend David Dench jailed over fraud. Sydney Morning Herald. June 27. Available online: https:// www.smh.com.au/national/football-legend-david-dench-jailed-over-fraud-20080627-2xoi.html (accessed on 4 December 2021).

Connolly, Michael. 2007. Measuring the effect of corruption on sovereign bond ratings. Journal of Economic Policy Reform 10: 309-23. [CrossRef]

Cooper, Graeme. 2017. What did we learn from Chevron? Australian Tax Review 46: 227-41.

Costigan, Frank. 2005. Australia's national integrity systems: Introducing a new blueprint. Australian Journal of Public Administration 64: $40-41$

Cowdery, Nicholas. 2020. Progress at last but are we headed for a Clayton's Commission? Law Society Journal 73: 69-71.

Davies, Anne. 2020. Berejiklian concedes $\$ 140 \mathrm{~m}$ grant scheme was pork-barrelling, but says 'it's not unique to our government. The Guardian, November 26. Available online: https:/ /www.theguardian.com/australia-news/2020/nov/26/berejiklian-admits-14 0m-grant-scheme-was-pork-barrelling-as-approval-documents-revealed (accessed on 4 December 2021).

Deeming, Christopher. 2014. Social democracy and social policy in neoliberal times. Journal of Sociology 50: 577-600. [CrossRef] [PubMed]

dela Rama, Marie, and Chris Rowley. 2017. The Changing Face of Corruption in the Asia-Pacific. Amsterdam: Elsevier. 
dela Rama, Marie, and Michael Lester. 2019. Anti-corruption commissions: Lessons for the Asia-Pacific region from a proposed Australian federal anti-corruption watchdog. Asia-Pacific Business Review 25: 571-99. [CrossRef]

Dixon, Olivia. 2020. The Efficacy of Australia Adopting a Debarment Regime in Public Procurement. Federal Law Review 49: $122-48$. [CrossRef]

Doran, Matt. 2018. Margaret Cunneen appointed to Federal Government's integrity commission panel. ABC News, December 18. Available online: https: / www.abc.net.au/news/2018-12-18/cunneen-appointed-to-government-integrity-commission-panel/ 10630190 (accessed on 4 December 2021).

Edwards, Lindy. 2017. Political Donations in Australia: What the Australian Electoral Commission Disclosures Reveal and What They Don't. Australian Journal of Public Administration 77: 392-403. [CrossRef]

Elmas, Matthew. 2020. Anti-corruption chiefs: Public hearings and independent funding indispensable to integrity. The Mandarin, November 5. Available online: https:/ / www.themandarin.com.au/144348-icac-public-hearings / (accessed on 4 December 2021).

Elysée Palace. 2021. Press Release. October 28. Available online: https://au.ambafrance.org/IMG/pdf/10_28_press_release_1_.pdf?13 816/9ecc1b7fe240344e1bb19e243a3ae2f0b9a024ea (accessed on 4 December 2021).

Emba, Christine. 2021. Video made police injustice invisible: Now that visibility is trickling up to the courts. Washington Post, November 17. Available online: https:/ /www.washingtonpost.com/opinions/2021/11/17/kyle-rittenhouse-trial-video-biasinjustice-exposure/ (accessed on 4 December 2021).

Feik, Nick. 2021. The scandals he walks past: In Morrison's government, a lack of accountability has become systemic. The Monthly, February 1. Available online: https:/ / www.themonthly.com.au/issue/2021/february/1612098000/nick-feik/scandals-he-walkspast\#mtr (accessed on 4 December 2021).

France, Guilherme. 2021. Overview of Lifestyle Audits as an Anti-Corruption Tool and Country Examples from Africa. Transparency International Anti-Corruption Help Desk. July 12. Available online: https://knowledgehub.transparency.org/assets/uploads/ kproducts/Helpdesk-Answer-2021_-Lifestyle-Audits.pdf (accessed on 4 December 2021).

Gilligan, George. 2018. The Hayne royal commission and trust issues in the regulation of the Australian financial sector. Law and Financial Markets Review 12: 175-85. [CrossRef]

Grafton, R. Quentin, and John Williams. 2020. Rent-seeking behaviour and regulatory capture in the Murray-Darling basin, Australia. International Journal of Water Resources Development 36: 484-504. [CrossRef]

Greenberg, Theodore S., Larissa Gray, Delphine Schantz, Carolin Gardner, and Michael Latham. 2010. Politically Exposed Persons: Preventive Measures for the Banking Sector. Washington, DC: World Bank Group.

Griffith University and Transparency International Australia. 2017. A Federal Anti-Corruption Agency for Australia? Discussion Paper No. 1. November. Available online: https:/ / apo.org.au/sites/default/files/resource-files/2017-03/apo-nid74719.pdf (accessed on 4 December 2021).

Gupta, Sanjeev, Luiz de Mello, and Raju Sharan. 2001. Corruption and military spending. European Journal of Political Economy 17: 749-77. [CrossRef]

Halpin, Darren, and John Warhurst. 2015. Commercial Lobbying in Australia: Exploring the Australian Lobby Register. Australian Journal of Public Administration 75: 100-11. [CrossRef]

Harris, Robert. 2003. Political Corruption. London: Routledge.

Harrison, Dan. 2015. Ebola treatment centre company Aspen Medical donated $\$ 15,000$ to Liberal Party. Sydney Morning Herald, February 3. Available online: https:/ / www.smh.com.au/politics/federal/ebola-treatment-centre--company-aspen-medicaldonated-15000-to-liberal-party-20150203-13506x.html (accessed on 4 December 2021).

Hasler, Olivia. 2020. Mining as ecocide: The case of Adani and the Carmichael mine in Australia. In Illegal Mining: Organized Crime, Corruption and Ecocide in a Resource-Scarce World. Edited by Yuliya Zabyelina and Daan van Uhm. London: Palgrave-Macmillan, pp. $497-527$.

Haynie, Stacia. 1998. Paradise lost: Politicization of the Philippine supreme court in the post-Marcos era. Asian Studies Review 22: 459-73. [CrossRef]

Heilbrunn, John R. 2004. Anti-Corruption Commissions: Panacea or Real Medicine to Fight Corruption? Washington, DC: World Bank Institute.

Hobbs, Harry, and George Williams. 2017. The case for a national whole-of-government anti-corruption body. Alternative Law Journal 42: 178-83. [CrossRef]

Huberts, Leo. 2014. The Integrity of Governance: What Is, What We Know, What Is Done and Where To Go. London: Palgrave Macmillan.

ICGN. 2017. Political Lobbying and Donations. Available online: https://www.icgn.org/sites/default/files/ICGN\%20Political\%20 Lobbying\%20\%26\%20Donations\%202017.pdf (accessed on 4 December 2021).

ICGN. 2021. Annual Review 2020-2021. Available online: https://www.icgn.org/sites/default/files/ICGN\%20Annual\%20Review\%20 2020\%20-\%202021\%20Final.pdf (accessed on 4 December 2021).

Jackson, Michael, Elizabeth Kirby, Rodney Smith, and Lynn Thompson. 2008. Sovereign eyes: Legislators' perceptions of corruption. Journal of Commonwealth and Comparative Politics 32: 54-67. [CrossRef]

Janda, Michael. 2020. Westpac's record \$1.3 billion AUSTRAC money laundering fine explained. ABC News, September 24. Available online: https:/ / www.abc.net.au/news/2020-09-24/westpac-money-laundering-austrac-fine-explained/12696746 (accessed on 4 December 2021). 
Johnson, Maggie, and Charles Livingstone. 2021. Measuring influence: An analysis of Australian gambling industry political donations and policy decisions. Addiction Research and Theory 29: 196-204. [CrossRef]

Kafteranis, Dimitrios. 2021. The international legal framework on whistleblowers: What more should be done? Seattle Journal for Social Justice 19: 729-58.

Kirby, Michael. 2009. Herbert Vere Evatt, the United Nations and the Universal Declaration of Human Rights after 60 years. University of Western Australia Law Review 34: 238-60.

Kirby, Nikolas. 2020. An 'institution-first' conception of public integrity. British Journal of Political Science 51: 1620-35. [CrossRef]

Knaus, Christopher. 2020. Police union condemns federal corruption commission as a 'protection racket' for government MPs. The Guardian, November 12. Available online: https://www.theguardian.com/australia-news/2020/nov/12/police-unioncondemns-federal-corruption-commission-as-a-protection-racket-for-government-mps (accessed on 4 December 2021).

Knaus, Christopher. 2021a. Christopher Pyne's firm hired by defence contractor awarded $\$ 98 \mathrm{~m}$ in government work while he was minister. The Guardian, January 28. Available online: https:/ / www.theguardian.com/australia-news/2021/jan/28/christopher-pynesfirm-hired-by-defence-contractor-awarded-98m-in-government-work-while-he-was-minister (accessed on 4 December 2021).

Knaus, Christopher. 2021b. Major Australian aged care provider reveals 15\% of staff vaccinated as sector demands changes to rollout. The Guardian, July 8. Available online: https://www.theguardian.com/australia-news/2021/jul/08/major-australian-aged-careprovider-reveals-just-15-of-staff-vaccinated-as-sector-demands-changes-to-rollout (accessed on 4 December 2021).

Larmour, Peter. 2001. Corruption, culture and transferability: What can be learned from Australia? Journal of Contingencies and Crisis Management 9: 14-20. [CrossRef]

Lawder, David. 2021. U.S. Chamber CEO slams Trump for undermining U.S. democracy. Reuters, January 13. Available online: https:/ / www.reuters.com/article/us-usa-trump-chamber-idUSKBN29H2PM (accessed on 4 December 2021).

Layton, Peter. 2019. Australia's F-35s: Lessons from a problematic purchase. The Lowy Institute Interpreter, November 11. Available online: https: / / www.lowyinstitute.org/the-interpreter/australia-s-f-35s-lessons-from-problematic-purchase (accessed on 4 December 2021).

Leng, Alyssa. 2020. The Najib verdict and the test of Malaysia's institutions. Lowy Institute: The Interpreter, August 4. Available online: https:/ / www.lowyinstitute.org/the-interpreter/najib-verdict-and-test-malaysia-s-institutions (accessed on 4 December 2021).

Leong, Shane, and James Hazelton. 2017. Improving corporate political donations disclosure: Lessons from Australia. Social and Environmental Accountability Journal 37: 190-202. [CrossRef]

Lester, Michael, and Marie dela Rama. 2018. Neo-Protectionism in the Age of Brexit and Trump-What does Australia do with its Powerful Friends? In Revisiting Globalization: From a Borderless World to a Gate Globe. Edited by Roopinder Oberoi and Jamie P. Halsall. Berlin: Springer, pp. 91-119.

Lester, Michael, Marie dela Rama, and Julie Crews. 2021. COVID-19 governance, legitimacy and sustainability: Lessons from the Australian experience. Corporate Governance and Sustainability Review 5: 143-53. [CrossRef]

Lewis, Colleen. 2021. Porter's commission is missing the integrity. Canberra Times, January 4. Available online: https://www. canberratimes.com.au/story/7073178/porters-commission-is-missing-the-integrity/ (accessed on 4 December 2021).

Livingston, Angus. 2019. Integrity watchdog bill ready this year. Canberra Times, September 11. Available online: https://www. canberratimes.com.au/story/6378772/integrity-watchdog-bill-ready-this-year/ (accessed on 4 December 2021).

Lu, Yi, Greg Shailer, and Mark Wilson. 2016. Corporate political donations: Influences from directors' networks. Journal of Business Ethics 135: 461-81. [CrossRef]

Lucas, Clay, and Ben Schneiders. 2020. Medical firm with ex-health minister as lobbyist wins $\$ 1.2 \mathrm{~B}$ of work. The Age, August 5 . Available online: https://www.theage.com.au/politics/victoria/medical-firm-with-ex-health-minister-as-lobbyist-wins-1-2bof-work-20200805-p55iti.html (accessed on 4 December 2021).

Lucas, Clay. 2021. Big Liberal donor among health firms selected to run vaccine rollout. Sydney Morning Herald, April 30. Available online: https:/ / www.smh.com.au/politics/federal/big-liberal-donor-among-health-firms-selected-to-run-vaccine-rollout-20 210427-p57my4.html (accessed on 4 December 2021).

Macallister, Ian. 2014. Corruption and confidence in Australian political institutions. Australian Journal of Political Science 49: 174-85. [CrossRef]

Marsh, David, Chris Lewis, and Jenny Chesters. 2014. The Australian mining tax and the political power of business. Australian Journal of Political Science 49: 711-25. [CrossRef]

Mayers, Lily. 2019. Eddie Obeid leaves Silverwater jail after spending three years behind bars. ABC News, December 14 . Available online: https:/ / www.abc.net.au/news/2019-12-14/eddie-obeid-granted-parole-after-spending-three-years-in-jail/11800078 (accessed on 4 December 2021).

McClymont, Kate, and Linton Besser. 2014. He Who Must Be Obeid: The Untold Story. Sydney: Random House Australia.

McKeown, Deirdre. 2014. Who Pays the Piper? Rules for Lobbying Governments in Australia, Canada, UK and USA. Research Paper. Australian Parliamentary Library. Available online: https://www.aph.gov.au/About_Parliament/Parliamentary_Departments/ Parliamentary_Library/pubs/rp/rp1415/LobbyingRules (accessed on 4 December 2021).

Meagher, Patrick. 2005. Anti-corruption agencies: Rhetorics versus reality. Journal of Policy Reform 8: 69-103. [CrossRef]

Mehafdi, Messaoud. 2000. The ethics of international transfer pricing. Journal of Business Ethics 28: 365-81.

Menz, Mario. 2021. Show me the money-managing politically exposed persons (PEPs) risk in UK financial services. Journal of Financial Crime 28: 968-80. [CrossRef] 
Mesmer-Magnus, Jessica R., and Chockalingam Viswesvaran. 2005. Whistleblowing in organizations: An examination of correlates of whistleblowing intentions, actions and retaliation. Journal of Business Ethics 62: 277-97. [CrossRef]

Miller, David, and William Dinan. 2008. Corridors of power: Lobbying in the UK. Observatoire de la Societe Britannique 6: $28-45$. [CrossRef]

Mitchell, Alex. 2015. ICAC a victim of its own success. Crikey, March 9. Available online: https://www.crikey.com.au/2015/03/09 /icac-a-victim-of-its-own-success / (accessed on 4 December 2021).

Mitchell, Ronald K., Bradley R. Agle, and Donna J. Wood. 1997. Toward a theory of stakeholder identification and salience: Defining the principle of who and what really counts. Academy of Management Review 22: 853-86. [CrossRef]

Mizen, Ronald. 2020. COVID-19 contracts drive Aspen Medical to windfall profit. Financial Review, December 14. Available online: https:/ / www.afr.com/politics/federal/ covid-19-contracts-drive-aspen-medical-to-windfall-profit-20201210-p56mc4 (accessed on 4 December 2021).

Morrison, Scott. 2021. Transcript of Interview with David Koch. In Sunrise. October 5. Available online: https://www.pm.gov.au/ media/interview-david-koch-sunrise-15 (accessed on 4 December 2021).

Mulgan, Richard. 2007. Truth in government and the politicisation of public service advice. Public Administration 85: 569-86. [CrossRef]

Murray, Georgina. 2006. Capitalist Networks and Social Power in Australia and New Zealand. London: Routledge.

Ng, Yee-Fui, Maria O'Sullivan, and Andrea Olivares-Jones. 2021. Submission to the Commonwealth Integrity Bill. Melbourne: Castan Centre for Human Rights Law, Faculty of Law, Monash University, February 12. Available online: https://www.monash. edu/_data/assets/pdf_file/0006/2487498/Monash-Law-submission-to-Integrity-Commission-BIll-2021.pdf (accessed on 4 December 2021).

NSW Government. 2021. Gladys Berejiklian Statement-Released by the Premier. Media release. October 1. Available online: https: / / www.nsw.gov.au/media-releases/gladys-berejiklian-statement (accessed on 4 December 2021).

NSW ICAC. 2014. Investigation into the Conduct of the Hon Edward Obeid MLC and Others Concerning Circular Quay Retail Lease Policy. Available online: https: / / www.parliament.nsw.gov.au/tp/files/63295/The\%20Hon\%20Edward\%20Obeid\%20MLC\%20and\% 20others\%20re\%20Circular\%20Quay\%20Retail\%20Lease.pdf (accessed on 4 December 2021).

NSW ICAC. 2019. Accountability Mechanisms. Available online: https:/ / www.icac.nsw.gov.au/about-the-nsw-icac/independence-andaccountability/accountability-mechanisms (accessed on 4 December 2021).

NSW ICAC. 2020. Operation Keppel. Available online: https://www.icac.nsw.gov.au/investigations/current-investigations/2020 / former-nsw-mp-for-wagga-wagga-operation-keppel (accessed on 4 December 2021).

NSW ICAC. 2021. Transcript of Intercepted Communication Exhibit 528: Call May 7th 2018. In Operation Keppel.. Available online: https: / / www.icac.nsw.gov.au/investigations/current-investigations/2020/former-nsw-mp-for-wagga-wagga-operation-keppel (accessed on 4 December 2021).

OECD Working Group on Bribery. 2019. Phase 4 Two Year Follow-Up Report: Australia. Available online: http://www.oecd.org/ corruption/anti-bribery/Australia-Phase-4-Two-Year-Written-Follow-Up-Report-ENG.pdf (accessed on 4 December 2021).

OECD. 2011. Asset Declarations for Public Officials: A Tool to Prevent Corruption. Paris: OECD Publishing, Available online: http: //www.oecd.org/corruption/anti-bribery/47489446.pdf (accessed on 4 December 2021).

Packer, George. 2020. The President Is Winning His War on American Institutions: How Trump is destroying the civil service and bending the government to his will. In The Atlantic. April. Available online: https://www.theatlantic.com/magazine/archive/20 20/04/how-to-destroy-a-government/606793/ (accessed on 4 December 2021).

Pellegatta, Alessandro, and Vincenzo Memoli. 2016. Can corruption erode confidence in political institutions among European countries? Comparing the effects of different measures of perceived corruption. Social Indicators Research 128: 391-412. [CrossRef]

Pender, Kieran, and Bill Browne. 2021. Whistleblower protections have never been more urgent. Canberra Times, November 26. Available online: https:/ / www.canberratimes.com.au/story / 7525875/whistleblower-protections-have-never-been-moreurgent/ (accessed on 4 December 2021).

Peruvian Ministry of Foreign Relations. 2019. Joint Presidential Declaraction-Peru-Colombia, 27th May. Available online: https: //www.gob.pe/institucion/rree/noticias/28812-declaracion-presidencial-conjunta-peru-colombia/ (accessed on 4 December 2021).

Prenzler, Tim, Bricklyn Horne, and Alex McKean. 2018. Identifying and Preventing Gray Corruption in Australian Politics. In Fraud and Corruption: Mayor Types, Prevention and Control. Edited by Peter C. Kratcoski and Maximilian Edelbacher. Berlin: Springer, pp. 61-81.

Quiggin, John. 1999. Globalisation, neoliberalism and inequality in Australia. Economics and Labour Relations Review 10: 240-59. [CrossRef]

Ramsay, Ian, Geoff Stapledon, and Joel Vernon. 2001. Political donations by Australian companies. Federal Law Review 29: 179-221. [CrossRef]

Robertson, Narelle M., Gary Sacks, and Peter G. Miller. 2019. The revolving door between government and the alcohol, food and gambling industries in Australia. Public Health Research and Practice 29: e2931921. Available online: https://www.phrp.com.au/issues/ september-2019-volume-29-issue-3/the-revolving-door-between-government-and-the-alcohol-food-and-gambling-industries-inaustralia/ (accessed on 4 December 2021). [CrossRef] [PubMed]

Rose-Ackerman, Susan. 1999. Political Corruption and Democracy. Connecticut Journal of International Law 14: 363-78.

Rose-Ackerman, Susan. 2008. Corruption and Government. International Peacekeeping 15: 328-43. [CrossRef] 
Sampford, Charles, Rodney Smith, and A. J. Brown. 2005. From Greek temple to bird's nest: Towards a theory of coherence and mutual accountability for national integrity systems. Australian Journal of Public Administration 64: 96-108. [CrossRef]

Schneider, Ben Ross. 1993. The career connection: A comparative analysis of bureaucratic preferences and insulation. Comparative Politics 25: 331-50. [CrossRef]

Schutte, Sofie Arjon. 2012. Against the odds: Anti-corruption reform in Indonesia. Public Administration and Development 32: 38-48. [CrossRef]

Schwartz, Herman. 1998. Social democracy going down or down under: Institutions, Internationalized Capital and Indebted States. Comparative Politics 30: 253-72. [CrossRef]

Scott, Andrew. 2009. Looking to Sweden in order to reconstruct Australia. Scandinavian Journal of History 34: 330-52. [CrossRef]

Senate Standing Committee on Finance and Public Administration. 2019. Compliance by Former Ministers of State with the Requirements of the Prime Minister's Statement of Ministerial Standards. Canberra: Commonwealth of Australia. Available online: https://www.aph. gov.au/Parliamentary_Business/Committees/Senate/Finance_and_Public_Administration/MinisterialStandards/Report (accessed on 4 December 2021).

Shill, Gregory H. 2020. Congressional securities trading. Indiana Law Journal 96: 313-36. [CrossRef]

Shleifer, Andrei, and Robert W. Vishny. 1993. Corruption. Quarterly Journal of Economics 108: 599-617. [CrossRef]

Siddiquee, Noore Alam, and Habib Zafarullah. 2020. Absolute Power, Absolute Venality: The Politics of Corruption and Anticorruption in Malaysia. Public Integrity. [CrossRef]

Sinanidis, Mary. 2021. Court hears that 'everything went bad' went St Basil's staff were pulled out. Neos Kosmos, November 17. Available online: https:/ / neoskosmos.com/en/2021/11/17/news/court-hears-that-everything-went-bad-when-st-basils-staffwere-pulled-out/ (accessed on 4 December 2021).

Soreide, Tina. 2007. Business Corruption: Speak out or take part? In Global Corruption Report 2007: Corruption in Judicial Systems. Edited by International Transparency. Cambridge: Cambridge University Press, pp. 338-441. Available online: https://images. transparencycdn.org/images/2007_GCR_EN.pdf (accessed on 4 December 2021).

Tanner, Stephen. 1995. Defining political corruption in light of the Metherell inquiry. Legislative Studies 10: 48-57.

Temby, Ian. 1991. ICAC: Working in the public interest. Current Issues in Criminal Justice 2: 11-16. [CrossRef]

The Australia Institute. 2019. Poll: 80\% of Australians Support a Federal Integrity Commission with Strong Powers, April 15. Available online: https:/ / australiainstitute.org.au/post/poll-80-of-australians-support-a-federal-integrity-commission-with-strong-powers/ (accessed on 4 December 2021).

Tobin, Grace. 2020. Crown Resorts whistleblower Jenny Jiang sues gambling giant over treatment in China. ABC 730 Report, December 15. Available online: https:/ / www.abc.net.au/news/2020-12-15/crown-whistleblower-sues-australian-gambling-giant/1298 3172 (accessed on 4 December 2021).

Transparency International Australia. 2020. Australia's National Integrity System. Available online: https://transparency.org.au/wpcontent/uploads/2020/11/NIS_04_Focus_Area_B_Web.pdf (accessed on 4 December 2021).

Transparency International. 2012. Corruption Perceptions Index. Available online: https://files.transparencycdn.org/images/CPI2012_ mapAndCountryResults.pdf (accessed on 4 December 2021).

Transparency International. 2021a. Corruption Perceptions Index. Available online: https://www.transparency.org/en/cpi/2020/table/ nzl (accessed on 4 December 2021).

Transparency International. 2021b. CPI 2020: Asia Pacific. Available online: https://www.transparency.org/en/news/cpi-2020-asiapacific (accessed on 4 December 2021).

Trautman, Lawrence J., and Kara Altenbaumer-Price. 2013. Lawyers, guns, and money: The bribery problem and the UK Bribery Act. International Lawyer 47: 481-517.

Treviño, Linda K., and Kate A. Nelson. 2021. Managing Business Ethics: Straight Talk about How to Do It Right. Hoboken: John Wiley \& Sons.

UN General Assembly. 2021. Resolution Adopted by the General Assembly on 2 June 2021. 32nd Special Session. Available online: https:/ / undocs.org/A/RES/S-32/1 (accessed on 4 December 2021).

UN Human Rights Office of the High Commissioner. 2020. Connecting the Business and Human Rights and the Anti-Corruption Agendas, Report of the Working Group on the Issue of Human Rights and Transnational Corporations and Other Business Enterprises. Report Number: A/HRC/44/43. Available online: https://www.ohchr.org/en/issues/business/pages/reports.aspx (accessed on 4 December 2021).

UN Office of Drugs and Crime. 2021. Ninth Session of the Conference of the State Parties to the United Nations Convention against Corruption. Available online: https://www.unodc.org/documents/treaties/UNCAC/COSP/session9/CU_2021_325A_English_ final_generic.pdf (accessed on 4 December 2021).

UNCAC Coalition. 2021. Submission to the 9th Session of the of the UNCAC Conference of the States Parties-Anti-Corruption Priorities in the Sub-Saharan African Region. November 26. Available online: https://www.unodc.org/documents/treaties/UNCAC/COSP/ session9/NGO/CAC-COSP-2021-NGO-28.pdf (accessed on 4 December 2021).

Uslaner, Eric M. 2002. The Moral Foundations of Trust. New York: Cambridge University Press.

Uslaner, Eric M. 2013. Trust and corruption revisited: How and why trust and corruption shape each other. Quality and Quantity 47: 3603-8. [CrossRef]

Uslaner, Eric M. 2017. Political corruption, trust and inequality. In Handbook on Political Trust. Edited by Sonja Zmerli and Tom W. G. van der Meer. London: Edward Elgar, pp. 302-15. 
Vallance, Sarah. 1999. Performance Appraisal in Singapore, Thailand and the Philippines: A Cultural Perspective. Australian Journal of Public Administration 58: 78-95. [CrossRef]

Warren, Mark E. 2004. What does corruption mean in a democracy? American Journal of Political Science 48: 328-43. [CrossRef]

White House. 2021. United States Strategy on Countering Countering Corruption. Available online: https://www.whitehouse.gov/wpcontent/uploads/2021/12/United-States-Strategy-on-Countering-Corruption.pdf (accessed on 4 December 2021).

Wilkins, Georgina. 2020. When it comes to picking stocks, one Liberal MP always has his finger on the pulse. Crikey, September 1. Available online: https://www.crikey.com.au/2020/09/01/dave-sharma-talent-for-picking-tech-stocks/ (accessed on 4 December 2021).

Williams, Robert. 1999. Democracy, development and anti-corruption strategies: Learning from the Australian experience. Commonwealth and Comparative Politics 37: 135-48. [CrossRef]

Wolf, Mark. 2018. The World Needs an International Anti-Corruption Court. Daedalus 147: 144-56. [CrossRef]

World Bank and Asian Development Bank (ADB). 2003. Philippines: Improving Government Performance = Discipline, Efficiency and Equity in Managing Public Resources; A Public Expenditure, Procurement and Financial Management Review. Report No. 24256. A joint document of the Government of the Philippines, Poverty Reduction and Economic Management Unit of the World Bank's East Asia and Pacific Region and the Asian Development Bank's Philippine Country Office. April 30. Available online: https:/ / openknowledge.worldbank.org/handle/10986/14616 (accessed on 4 December 2021).

Yeh, Stuart S. 2021. APUNCAC and the International Anti-Corruption Court (IACC). Laws 10: 1. [CrossRef] 